\title{
Overview and future challenges of nearly Zero Energy Buildings (nZEB) design in Southern Europe
}

Article in Energy and Buildings · September 2017

DOI: 10.1016/j.enbuild.2017.09.043

CITATIONS

2

16 authors, including:

\section{Shady Attia}

University of Liège

56 PUBLICATIONS 760 CITATIONS

SEE PROFILE

\section{Flouris Xeni}

Cyprus University of Technology

4 PUBLICATIONS 8 CITATIONS

SEE PROFILE
READS

304

\section{Polyvios C. Eleftheriou}

Cyprus University of Technology

51 PUBLICATIONS 248 CITATIONS

SEE PROFILE

\section{Christophe Ménézo}

Université Savoie Mont Blanc / Polytech'Ann... 143 PUBLICATIONS 999 CITATIONS

SEE PROFILE

Some of the authors of this publication are also working on these related projects:

Project More-Connect View project

Project

Heat exchangers View project 


\title{
Overview and future challenges of nearly zero energy buildings (nZEB) design in Southern Europe
}

\author{
Shady Attia ${ }^{a, *}$, Polyvios Eleftheriou $^{\mathrm{b}}$, Flouris Xeni ${ }^{\mathrm{b}}$, Rodolphe Morlot ${ }^{\mathrm{c}}$, \\ Christophe Ménézo ${ }^{\mathrm{d}}$, Vasilis Kostopoulos ${ }^{\mathrm{e}}$, Maria Betsi ${ }^{\mathrm{e}}$, Iakovos Kalaitzoglou ${ }^{\mathrm{e}}$, \\ Lorenzo Pagliano $^{\mathrm{f}}$, Maurizio Cellura ${ }^{\mathrm{g}}$, Manuela Almeida ${ }^{\mathrm{h}}$, Marco Ferreira ${ }^{\mathrm{h}}$, Tudor Baracu ${ }^{\mathrm{i}}$ \\ , Viorel Badescu ${ }^{\mathrm{i}}$, Ruxandra Crutescu ${ }^{\mathrm{j}}$, Juan Maria Hidalgo-Betanzos ${ }^{\mathrm{k}}$ \\ a Sustainable Buildings Design Lab, Dept. UEE, Faculty of Applied Sciences, Univeristé de Liège, Belgium \\ ${ }^{\mathrm{b}}$ Department of Mechanical Engineering and Materials Science and Engineering, Faculty of Engineering, Cyprus University of Technology, Limassol, Cyprus \\ ${ }^{\mathrm{c}}$ Grids and Renewable Energy Department, French Environment and Energy Management National Agency (ADEME), Valbonne Sophia-Antipolis, France \\ d University Savoie Mont Blanc, LOCIE UMR CNRS 5271, National Institute of Solar Energy (INES), Le Bourget-du-Lac, France \\ e Applied Mechanics Laboratory, Department of Mechanical Engineering and Aeronautics, University of Patras, GR-26500 Patras, Greece \\ ${ }^{f}$ end-use Efficiency Research Group, Politecnico di Milano Dipartimento di Energia Via Lambruschini 4, 20156 Milano, Italy \\ ${ }^{g}$ Dipartimento di Energia, Ingegneria dell'Informazione e Modelli Matematici - Università degli Studi di Palermo, Palermo, Italy

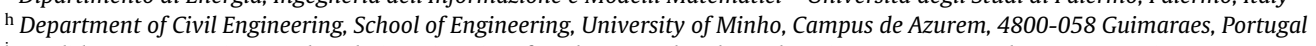 \\ i Candida Oancea Institute, Polytechnic University of Bucharest, Spl. Independentei 313, 060042 Bucharest, Romania \\ j Spiru Haret University, Faculty of Architecture,Ion Ghica Street, no. 13, 030045, Bucharest, Romania \\ ${ }^{k}$ ENEDI RG, Department of Thermal Engineering, University of the Basque Country UPV/EHU, Europa 1, 20018 Donostia-San Sebastian, Spain
}

\section{A R T I C L E I N F O}

Article history:

Received 26 October 2016

Received in revised form 19 August 2017

Accepted 15 September 2017

\section{Keywords:}

Renovation

Nearly zero energy building (nZEB)

Net zero energy building (NZEB)

Fuel poverty

Thermal comfort

EPBD

Warm climate

Construction quality

\begin{abstract}
A B S T R A C T
In times of great transition of the European construction sector to energy efficient and nearly zero energy buildings (nZEB), a market observation containing qualitative and quantitative indications should help to fill out some of the current gaps concerning the EU 2020 carbon targets. Next to the economic challenges, there are equally important factors that hinder renovating the existing residential building stock and adding newly constructed high performance buildings. Under these circumstances this paper summarises the findings of a cross-comparative study of the societal and technical barriers of nZEB implementation in 7 Southern European countries. The study analyses the present situation and provides an overview on future prospects for nZEB in Southern Europe. The result presents an overview of challenges and provides recommendations based on available empirical evidence to further lower those barriers in the European construction sector. The paper finds that the most Southern European countries are poorly prepared for nZEB implementation and especially to the challenge/opportunity of retrofitting existing buildings. Creating a common approach to further develop nZEB targets, concepts and definitions in synergy with the climatic, societal and technical state of progress in Southern Europe is essential. The paper provides recommendations for actions to shift the identified gaps into opportunities for future development of climate adaptive high performance buildings.
\end{abstract}

(C) 2017 Elsevier B.V. All rights reserved.

\section{Introduction}

The Climate-Energy Framework 2020 sets three key targets to cut $20 \%$ in green gas emissions (compared to 1990 levels), increase the EU renewables share by $20 \%$ and improve energy efficiency by $20 \%$ [1]. The main instrument to achieve those targets in the build-

\footnotetext{
* Corresponding author at: Univeristé de Liège, Sustainable Buildings Design Lab, Office +0/542, Quartier Polytech 1, Allée de la Découverte 13A, 4000 Liège, Belgium. E-mail address: shady.attia@ulg.ac.be (S. Attia).
}

ing sector is the Energy Performance of Building Directive (EPBD) recast that sets the standards for new and renovated buildings across Europe. The Directive 2010/31/EU (EPBD) at Art. 9 indicates that EU Member States (MS) must ensure that by 2021 all new buildings, and already by 2019 all new public buildings, are nearly Zero Energy Buildings (nZEB) and MS should draft plans and "...encourage best practices as regards the cost-effective transformation of existing buildings into nearly zero-energy buildings" [2]. Accordingly, most MS revised recently the existing rules, regulations and guidelines as well started to set up the means for increasing the penetration of those high performance buildings 


$\begin{array}{ll}\text { Nomenclature } \\ \text { AEC } & \text { Architectural, engineering and construction } \\ \text { AC } & \text { Air conditioning } \\ \text { ACH } & \text { Air change per hour } \\ \text { BEPOS } & \text { Bâtiment à énergie positive } \\ \text { BPS } & \text { Building performance simulation; } \\ \text { CEN } & \text { European committee for standardization } \\ \text { DBT } & \text { Dry bulb temperature } \\ \text { DHW } & \text { Domestic hot water } \\ \text { EE } & \text { Energy efficiency } \\ \text { EPBD } & \text { Energy performance building directive } \\ \text { EPC } & \text { Energy performance certificate } \\ \text { EUI } & \text { Energy use intensity } \\ \text { EU } & \text { European Union } \\ \text { FIT } & \text { Feed-in tariff } \\ \text { HRV } & \text { Heat recovery ventilation } \\ \text { HVAC } & \text { Heating, ventilation and air conditioning } \\ \text { IEA } & \text { International Energy Agency } \\ \text { IEE } & \text { Intelligent Energy Europe } \\ \text { LCA } & \text { Life cycle assessment } \\ \text { MS } & \text { Member states } \\ \text { MVHR } & \text { Mechanical ventilation with heat recovery } \\ \text { nZEB } & \text { Nearly zero energy buildings } \\ \text { NZEB } & \text { Net zero energy buildings } \\ \text { OT } & \text { Operative temperature } \\ \text { PE } & \text { Primary energy } \\ \text { PEF } & \text { Primary energy factor } \\ \text { pH } & \text { Passive house } \\ \text { PMV } & \text { Predicted mean vote } \\ \text { PPD } & \text { Predicted percentage dissatisfied } \\ \text { PV } & \text { Photovoltaic } \\ \text { RES } & \text { Renewable energy systems } \\ \text { SCOP } & \text { Seasonal coefficient of performance } \\ \text { SEER } & \text { Seasonal energy efficiency ratio } \\ \text { SFP } & \text { Specific fan power } \\ \text { SHW } & \text { Solar hot water } \\ \text { SME } & \text { Small and middle enterprise } \\ \text { VRF } & \text { Variable refrigerant flow } \\ \text { WWR } & \text { Window to wall ratio } \\ & \end{array}$

by setting up the nZEB definitions on the national level. However, there are significant differences in the progress and implementation of nZEB across the 28 MS. From one side, Northern MS managed to develop or adapt concepts, definitions and construction technologies of nZEB that are effective and correspond to their heating dominated climates. The PassiveHouse $(\mathrm{pH})$ standard is an example for that. On the other side, Southern MB are still trying to find the most adequate solutions taking into account the local climate and local cultural, social, technical and economic context.

Therefore, the objective of this paper is to provide an overview on the technical and societal challenges of applying nZEB in Southern Europe. The overall aim is to provide a better understanding of nZEB and their market uptake barriers. The cost challenge is excluded from this study because it is discussed in other studies [3]. The study focus is mainly on countries falling between latitude $35^{\circ} \mathrm{N}$ and $45^{\circ} \mathrm{N}$ and includes a literature review of more than 95 publications on nZEB implementation in Southern Europe. For this study, we have selected 7 countries, namely Cyprus, France, Greece, Italy, Portugal, Romania and Spain, for which we could have access to representative information and insights. We find the selected countries as significant regarding their population size and buildings stock proportions that represent more than 33\% of the European residential buildings stock (see Fig. 1). The originality of the paper is twofold. The paper provides a broad overview on the challenges of nZEB bringing insights from 7 Southern member states, which was not done before. Also, the paper identifies possible synergies between similar climate regions, which can bring a consensus for best practices in Southern European countries regarding deep renovation, to bridge the energy gap and increase the nZEB uptake.

The methodology used consists of reviewing the state of the art in the 7 member states. The first part of the methodology is based on a literature and case studies review. The second part is based on a questionnaire. By proposing five key questions to 14 national experts from Cyprus, France, Greece, Italy, Portugal, Romania and Spain we developed the paper content with a focus on new and existing residential buildings. The five questions are listed below:

1. What is the minimum energy efficiency threshold for nZEB in your country?

2. What is the heating/cooling energy needs balance for nZEB in your country?

3. What is the thermal comfort limit for nZEB in your country?

4. What is the minimum renewables threshold for nZEB in your country? What are the recommendations for minimum EE and RET in your country? (EE energy efficiency, RET Renewable Energy Threshold onsite).

5. What is the construction quality for nZEB in your country?

A post processing phase followed the questionnaire results analysis. The analysis is based on facts tracing to allow the assessment of the existing possibilities and the status of the nZEB legislation and policies as they were applied in these countries in last few years. By this analysis we do not pretend to predict the future, but we can identify the features of the current nZEB situation and assess its development trends. Therefore, we have adopted the method of analysis looking at the social/political and technical backgrounds behind nZEB in Southern Europe. Finally, the analysis provides guidance on the challenges and constraints in each MS and provides an overall list of recommendations and conclusion for nZEB in Southern Europe. This paper is organized into four sections. The first section introduces the research and identifies the research problem, objective and significance. The second section provides an overview of the main challenges of nZEBs in Southern Europe from a technical and societal point of view. The third section summaries different approaches and barriers to implement nZEB in Southern Europe. The final section discusses and concludes the study outcomes, implications and limitation while providing useful recommendations.

\section{Nearly zero energy buildings in Southern Europe}

The zero energy buildings and zero carbon buildings goals seeking maximum efficiency derive from the notion of neutralizing the resource consumption and define this as zero energy consumption. The design process involves an integrative approach looking to:

1. reduce energy needs for heating and cooling by optimising the envelope and integrating passive heating and cooling techniques;

2. improve energy efficiency of active systems

3. and incorporate renewable energy.

Various potential definitions of Net Zero Energy Buildings (NZEB) were first discussed and proposed on an international level in 2008 [4]. Many of those definitions require a zero energy balance between energy used and generated (or imported from the grid and exported to the grid) over a certain time interval (e.g. a year or a month). Energy might be considered at the site ("delivered 


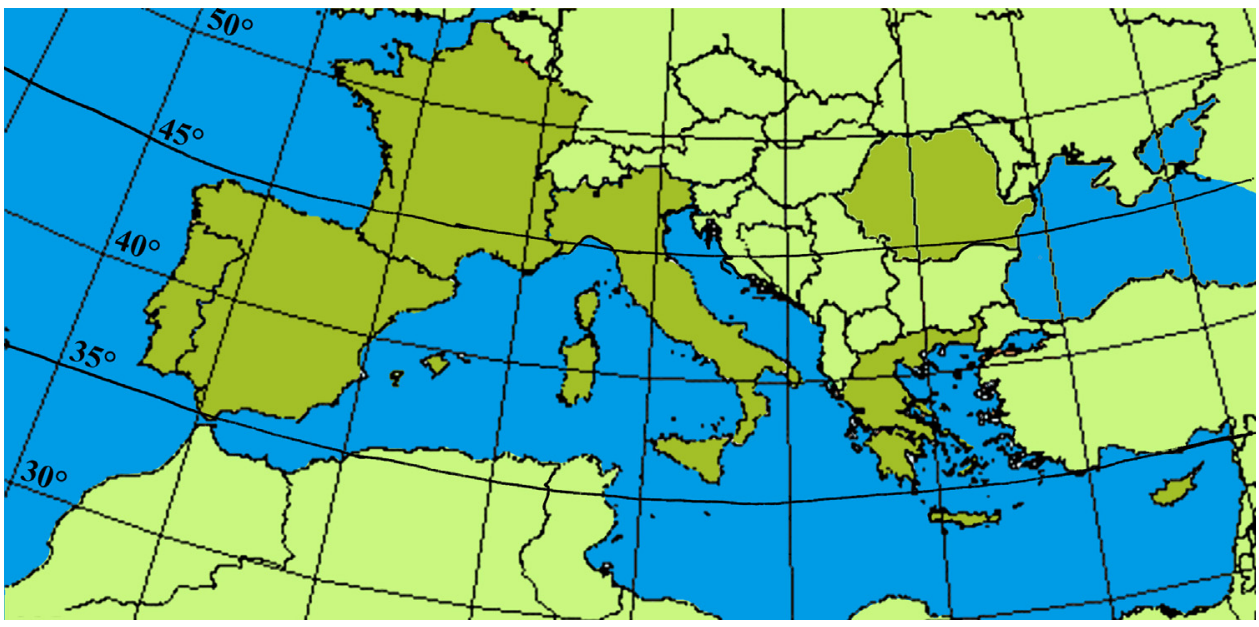

Fig. 1. The participating countries in the study on nearly Zero Energy Buildings status in Southern Europe.

energy", in EN and ISO nomenclature) or at source ("primary energy, in EN and ISO nomenclature). The International Energy Agency (IEA) compiled and discussed the earliest definitions within Task 40: Towards Net Zero Energy Buildings comprising almost 20 countries. USA was discussing the definitions within the Energy Independence and Security Act of 2007 and the European Union was discussing the definitions within the recast of the EPBD adopted in May 2010 [5-7].

The recast of the EPBD introduced the notion of 'nearly zero energy' buildings (nZEB) [7]. According to Article 2(2) of the EPBD an nZEB '....means a building that has a very high energy performance, as determined in accordance with Annex I. The nearly zero or very low amount of energy required should be covered to a very significant extent by energy from renewable sources, including energy from renewable sources produced on-site or nearby' Annex I states: “The energy performance of a building shall be determined on the basis of the calculated or actual annual energy that is consumed in order to meet the different needs associated with its typical use and shall reflect the heating energy needs and cooling energy needs (energy needed to avoid overheating) to maintain the envisaged temperature conditions of the building, and domestic hot water needs".

Hence the EU Directive introduces the requirement of acting first on the envelope of the building via the requirement that the building should have very low "energy needs".

All European Union (EU) MS had to engage in a more widespread deployment of such buildings by 2020. In addition, the MS are required to draw up national plans for increasing the number of nZEBs. These national plans can include differentiated targets according to the category of buildings. Recently, consultation and procedures have been held in the energy administrations of the national regions to respond to the European requirements. This makes the EU a leader in terms of introducing regulatory changes to adapt buildings to nZEB and NZEB. For this paper, we are looking to distill the most important lessons learned from the Southern European Countries experience. Up till now, there is no Cross-European understanding and agreement on the national implementation of the overarching definition given by EPBD.

The status of Southern European countries, shown in Table 1 in particular, reflects a serious problem of definition adoption and consequently market uptake. Despite the requirement of Annex I of EPBD that "the methodology for calculating the energy performance of buildings should take into account European standards" [8]; the nZEB definitions are subject to different market interpretations. This is in part due to the not sufficiently precise definition of "energy performance of a building" in annex I of the EPBD: "The energy performance of a building shall be expressed in a transparent manner and shall include an energy performance indicator and a numeric indicator of primary energy use, ...". This EPBD sentence requires the presence of two indicators but it is not completely precise in naming them. The Report "Towards NZEB" [1] prepared under a tender of the EU Commission and a report by eceee [9] recommended that 1) the first performance indicator should be explicitly specified as "energy needs for heating and cooling" in order to adhere to the logical choice of first reducing energy demand in order to avoid wasting valuable energy be it fossil or renewable, 2 ) the term "primary" energy should be specified (total or only the non renewable part, and as for the concept of (nearly) zero primary energy the annex should specify or give guidance on the issue of its calculation period (annual, monthly,...).

The following sections discuss the main challenges and their implications for setting a sustainable and practical nZEB definition and propose principles to be considered when setting up a practical definition.

\subsection{Minimum threshold energy efficiency}

For achieving high efficiency in buildings, an ambitious energy and carbon emissions reduction must be required for nZEB using commonly agreed and well specified indicators [2]. This would not limit the possibility to adapt the targets/thresholds level of those indicators to local conditions. On the other side, it would allow to have a common language across Europe which is essential for construction industry to develop solutions in a stable and coherent framework. This is essential since in 2020, all new buildings will have to demonstrate high energy performance and their reduced or ultra-low energy needs will be significantly covered by renewable energy sources (see Fig. 2). Clear definitions of the energy levels and their calculation/measurement steps are presented in the European Standards, revised a few years ago in view of the EPBD application. As defined in EN15603:2008, evaluation of energy efficiency of new building and retrofits require the calculation of energy needs for heating, cooling and hot water and energy use for lighting and ventilation. The same calculation procedure, starting from energy needs and uses and ending with primary energy, is detailed step by step in the EU official "Guidelines establishing a methodology framework for calculating cost-optimal levels of minimum energy performance requirements. For calculation of primary energy with primary energy factors, EN15603 presents explicit formulas, with degrees of flexibility for MS. For example, in Italy a nZEB definition coherent with the objective of first reducing the energy needs has been adopted where the non-renewable primary energy accounting should be done month by month, and excess energy e.g. sold 
Table 1

nZEBís legislation current status in Southern Europe's Member states [42,96].

\begin{tabular}{|c|c|}
\hline Country & Status \\
\hline BULGARIA & Still to be approved. No information is yet available \\
\hline CYPRUS & $\begin{array}{l}\text { National Plan is in place. Numerical indicators have been set for nZEB for both residential and non-residential buildings. A minimum } \\
\text { threshold for heating is set at } 15 \mathrm{kWh} / \mathrm{m}^{2} \text {.a. for residential buildings along with a PE of } 100 \mathrm{kWh} / \mathrm{m}^{2} / \mathrm{a} \text {. No cooling threshold has been set. A PE } \\
\text { of } 125 \mathrm{kWh} / \mathrm{m}^{2} / \mathrm{a} \text { has been set for non-residential buildings, but no minimum thresholds exist for either heating or cooling. }\end{array}$ \\
\hline FRANCE & $\begin{array}{l}\text { National Plan "Energy transition for green economic growth" is in place. The minimum threshold for cooling and heating is set at } \\
50 \mathrm{kWh} / \mathrm{m}^{2} \text {.a. The PE ranges from } 70 \text { to } 110 \mathrm{kWh} / \mathrm{m}^{2} / \mathrm{a} \text {. New labels regarding Positive energy building and low carbon (E+/C-) are currently } \\
\text { set up and foreshadow the new regulation planned for } 2018 \text {. }\end{array}$ \\
\hline GREECE & No report is yet available, thus no final information is available. \\
\hline HUNGARY & Still to be approved. No information is yet available. \\
\hline ITALY & $\begin{array}{l}\text { A national plan is available, prerequisite for NZEB is the achievement of energy performance higher than a reference building fixed by } \\
\text { regulations, while several more requirements are required to be fulfilled, regarding thermal renewable generation from renewable sources } \\
\text { (>=50\% of energy use for domestic hot water, >=50\% of energy use for domestic hot water, heating and cooling), thermal systems efficiencies, } \\
\text { overall average U coefficient, glazed areas/floor area ratio, energy needs for heating and cooling (lower than the reference building). }\end{array}$ \\
\hline MALTA & National Plan is under development. Annual PEC should not exceed $40 \mathrm{kWh} / \mathrm{m}^{2} / \mathrm{a}$. for dwellings and $\mathrm{kWh} / \mathrm{m}^{2}$.a. for others buildings \\
\hline PORTUGAL & $\begin{array}{l}\text { National Plan is in place. However, numerical indicators are not exactly stated and they depends on several variables including technical } \\
\text { viability, climate, type of construction, traditions, etc. }\end{array}$ \\
\hline ROMANIA & $\begin{array}{l}\text { National Plan is under development. Numerical indicators are not exactly stated and they depends on several variables including technical } \\
\text { viability, climate, type of construction, etc. }\end{array}$ \\
\hline SLOVENIA & Still to be approved. A National plan should consider nZEBs as the ones with an annual PE ranging from 45 to $50 \mathrm{kWh} / \mathrm{m}^{2} . \mathrm{a}$. \\
\hline SPAIN & $\begin{array}{l}\text { Still to be approved. A draft of nZEB indicators for Spain was published in December 2016, without specifying their limits. The proposed } \\
\text { indicators aim to define: maximum net PE use, maximum total PE use, minimum renewable contribution for the DHW generation, maximum } \\
\text { building global thermal transmittance, solar control considering the solar gains of July, maximum transmittances in housing enclosures, } \\
\text { verification of moisture risk of the envelope, and minimum EE values for the HVAC systems and lighting. }\end{array}$ \\
\hline
\end{tabular}

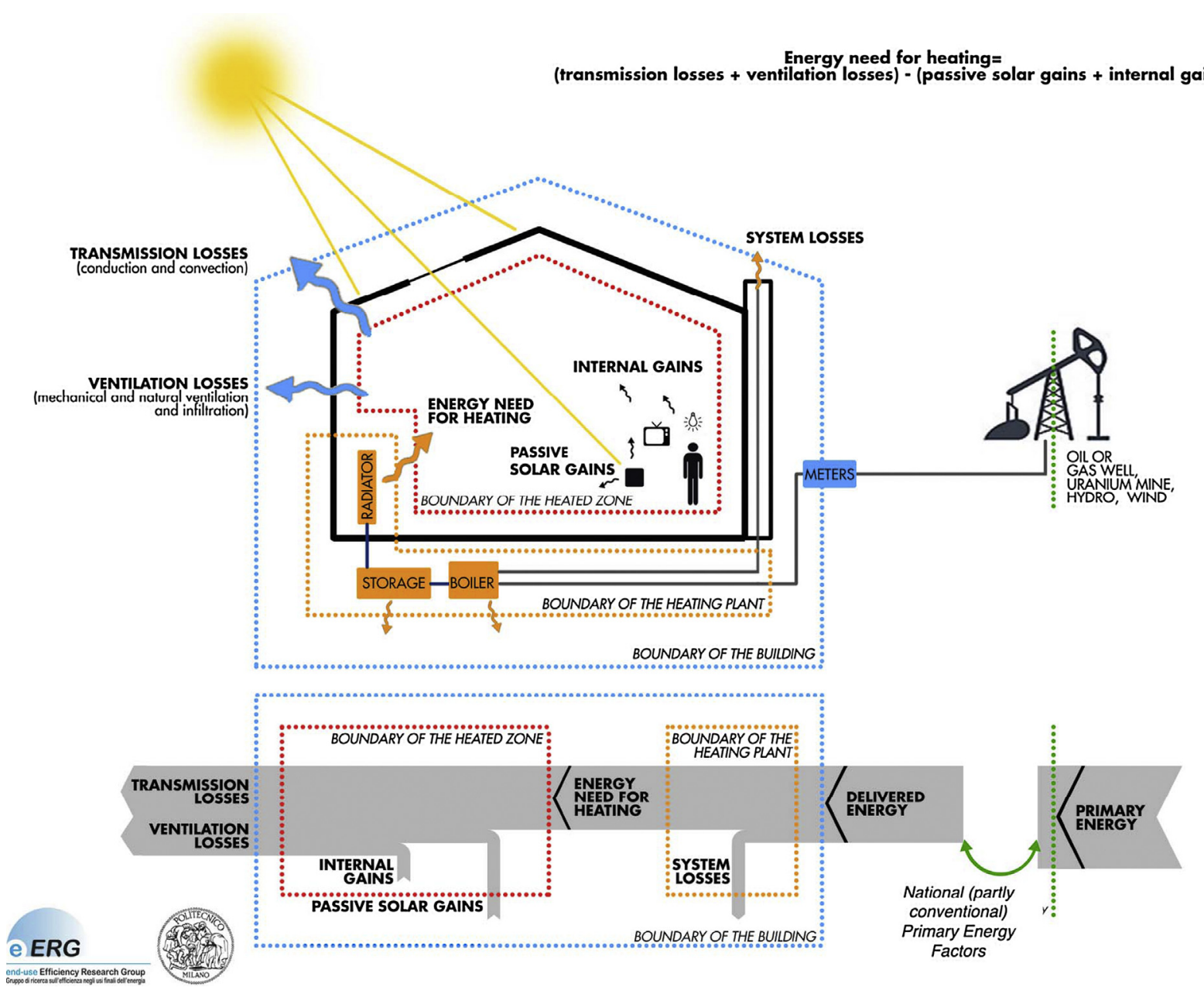

Fig. 2. Representations of energy levels according to EN standards, limited to the case of heating for sake of clarity [9].

to the grid in summer, cannot be used to compensate for excess demand in winter.

Given the unsatisfactory situation described above, a number of ambiguities and discrepancies have materialised in the national implementation phase of the nZEB concept. 'Zero energy' is often interpreted as 'net zero energy': i.e. balance between the consumed and produced energy on site although this concept is not present in EPBD. Also, due to the lack of policy definition for ultra-low energy 
buildings, initially different definitions were introduced by business networks and mixed business/policy networks in the recent years [10].

There are significant differences in the definition of the minimum building energy efficiency threshold performance among the Southern European Member states. The disparity is mainly due to the climatic, social, technological and economic variation between the countries, and this is partly justified. But more importantly the terminology and the definitions are not the same so comparisons are difficult or impossible. Already several European countries opt to comply with the $\mathrm{pH}$ Standard to guarantee that energy needs for heating and cooling are both below $15 \mathrm{kWh} /\left(\mathrm{m}^{2} /\right.$ year $)$. However, the $\mathrm{pH}$ Standard is sometimes perceived as a high-tech building design in construction approaches and hence not feasible across all of Europe. Therefore, the challenge to implement and comply with nZEB performance requirements is high. The challenge is not only for new construction but also for renovation. A more precise definition of the indicators such as the one proposed in $[11,9]$ would help in the future to move towards a stronger framework for the actors of the construction industry without restricting the flexibility allowed to MS.

\subsection{Heating-cooling balance}

The characterisation of the balance of heating and cooling energy needs is important for high performance buildings to limit unnecessary space conditioning systems and distribution. For example, in heating dominated climates designers seek to eliminate active cooling by using passive cooling design measures. This can lead to significant costs cuts due to the use of a single active mechanical system. The reason for that is to reduce cost and provide simple control and maintenance. In Northern Europe, it is possible to achieve relatively easily summer comfort conditions and hence concentrate the largest part of the design effort to reducing the energy need for heating and to dealing with a single active conditioning system of which to optimize size and costs. However, in South Europe higher summer temperatures and solar radiation result for most building typologies and designs in an equilibrium of heating and cooling energy needs, the necessity to solve potential conflicts between winter and summer comfort objectives, a higher probability of having to install both heating and cooling systems (active or passive or hybrid) and to bear the associated costs. The study of Badescu [12] suggests that an active cooling and heating system should be used when $\mathrm{pH}$ buildings are implemented in the mixed mode and hot climates.

The implications of a symmetric or quasi symmetric balance of heating and cooling energy needs lead often to the choice of dual active systems with thermal and electric energy demand and can have a large impact on initial cost, operational cost peak loads and energy supply networks. Passive cooling systems such as earth buried pipes for cooling, ventilation air, evaporative cooling, night sky radiation are also available but need a careful design and adaptation to climate, air and outdoor conditions (pollution, noise, mosquitos etc.), which requires highly skilled and savvy architects, engineers and builders. In warm climates, low energy needs thresholds for heating, e.g. 15 or $30 \mathrm{kWh} /\left(\mathrm{m}^{2}\right.$ year $)$, can be met more easily for heating than in cold ones $[13,14]$. This is due to milder weather and shorter extreme climatic cold waves. It is then possible to reduce heating needs even though various design parameters are not optimal (shapes, orientations, insulation, window sizes, performance of components, etc.). By reducing the envelop conductivity and infiltration and selecting optimal glazing and window openings, one can reduce heating energy demand significantly. In this context, aiming at 'nearly zero energy heating' targets to achieve the optimum savings is technically feasible. The use of heat recovery ventilation (HRV), also known as mechanical ventilation heat recovery (MVHR), can provide adequate space conditioning with minimum additional energy input and allows heat distribution directly through the air supply. In the case of Southern European climates, this could then make it possible to reach low heating energy demand values around $5 \mathrm{kWh} /\left(\mathrm{m}^{2}\right.$ year $)$. However, in Southern Europe limiting the energy need for cooling below $15 \mathrm{kWh} /\left(\mathrm{m}^{2}\right.$ year $)$ is not always possible due to high solar radiation, high outdoor ambient temperature and heat island effect in cities. Therefore, any definition for nZEB should be aware about the heating-cooling balance for every climatic zone in Southern Europe and require energy efficiency thresholds and recommend passive or efficient active systems solutions accordingly. In our review of challenges of nZEB, we will focus on how the heating-cooling balance principle is addressed in the current definitions.

\subsection{Thermal comfort limits}

Fig. 3 summarizes the evolution of comfort models in the last 50 years. The available models worldwide are mainly focused on office buildings, partly because of the limited number of surveys in the area of residential buildings, but the scope of these standards is then extended to "other buildings of similar type used mainly for human occupancy with mainly sedentary activities and dwelling" [15].

In 2007, the European Committee for Standardization (CEN) introduced the European standards EN 15251, which suggests the adoption of the Fanger's PMV/PPD model for mechanically heated and/or cooled buildings and Humphreys and Nicol's adaptive model for buildings without mechanical cooling systems. For nZEB short and long-term comfort indices should be calculated according to EN 15251 , in addition to energy performance indexes. The connection between thermal performance and comfort is explicitly mentioned in EPBD [9]. On the other hand, various organisations have made their own proposals for comfort targets, e.g. French regulation requires that in air conditioned buildings the set point temperature in summer should not be set below $26^{\circ} \mathrm{C}$; CIBSE Guide A defines 'overheating' as occurring when the operative temperature (OT) exceeds $28 \mathrm{C}$ for more than $1 \%$ of the annual occupied hours in the living areas of (free running) dwellings or when the bedroom OT exceeds $26 \mathrm{C}$ for more than $1 \%$ of the annual occupied hours (unless ceiling fans are available). The $\mathrm{pH}$ standard requires as a summer comfort criterion that "the number of hours in excess of $25^{\circ} \mathrm{C}$ may not exceed $5 \%$ of the time working". This criterion is verified by using a dynamic simulation". However, comfort as defined by $\mathrm{pH}$ may be challenging to be achieved via the passive techniques traditionally adopted in good quality construction in Southern Countries and may not correspond to what are the expectations of building occupants based on the prevailing climate, clothing habits and culture [11,16-20]. A discussion about the issue of definition of comfort objectives took place e.g. within the European project Passive-on, which involved experts from both northern and southern countries with the objective of exploring adaptation of the $\mathrm{pH}$ concept suitable for Mediterranean climates and lead to a recommendation to refer to EN15251, including the option to use adaptive comfort where suitable [21-23].

Recently, a discussion about sick buildings and risks of overheating has emerged. The number of studies addressing summer comfort in nZEB in Southern Europe based on measured data is by now limited. Some extensive simulation studies find overheating risks in conventional buildings and significant improvements when going to well-designed advanced buildings [24-28]. In $\mathrm{pH}$ es "summer comfort can be achieved only resourcing to passive improvements, without any active cooling system;" while "with common building envelope solutions and construction materials, typically used in Portugal, simulations showed long periods of thermal discomfort for the heating season, as well as long periods of 


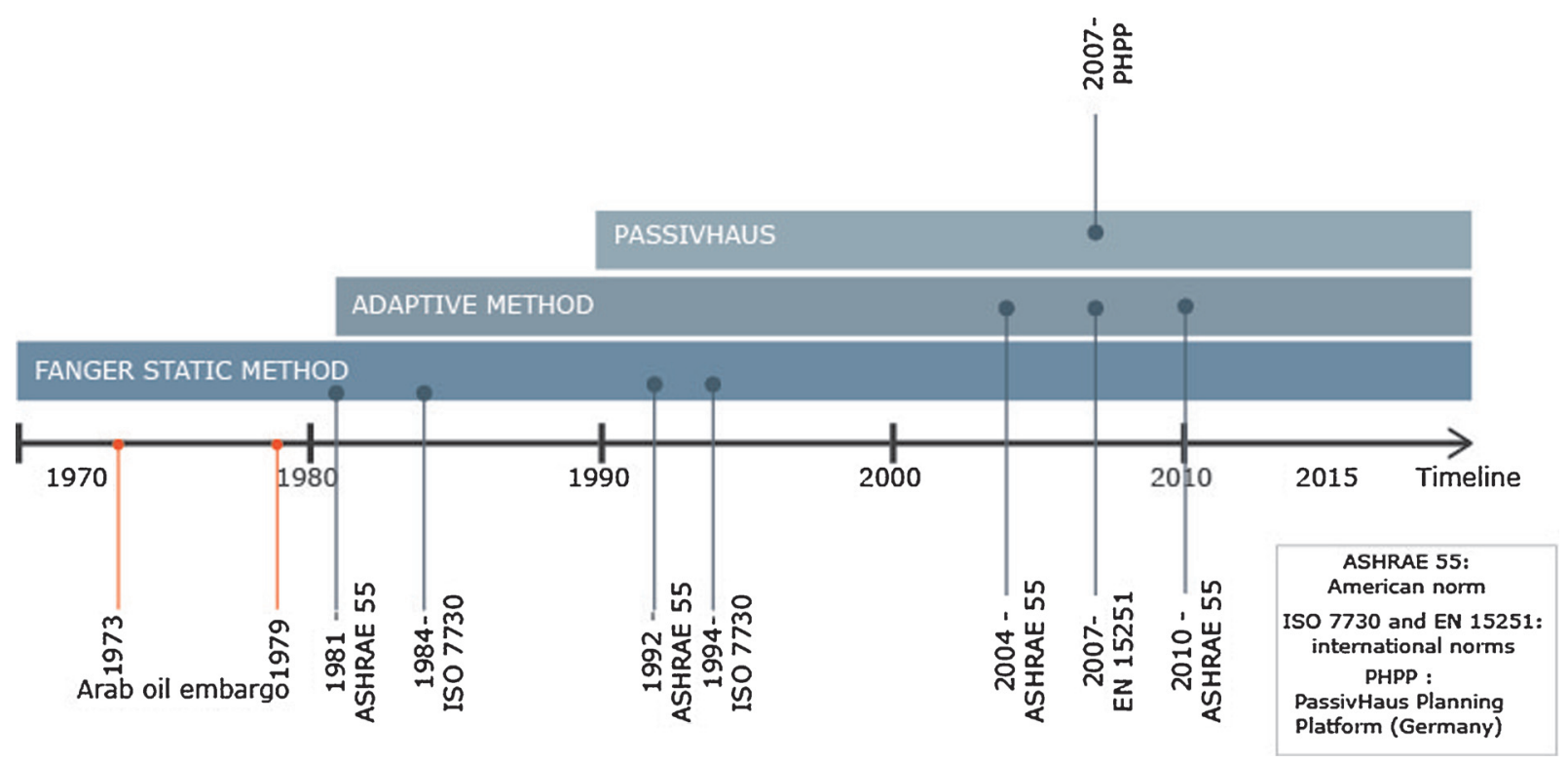

Fig. 3. Evolution of thermal comfort standards in the last 50 years [8].

overheating during the summer" [29]. The studies conducted in UK, Belgium and Netherlands [24-28] for different Passive House projects reported overheating periods during summer. The over focus on energy performance in nZEBs can lead to health and comfort problems. Badescu et al. reported excessive overheating hours in a Romanian case study and recommended the inclusion of active cooling systems for such high performance buildings [12]. However, the existence of various definitions of overheating and explicit indexes, including the long-term comfort indexes proposed in EN15251, are rarely used for designing buildings or assessing their actual comfort performance after occupation [30]. In this study, we consider adaptive thermal comfort standards helpful, to take advantage of the individual range of adaptive possibilities in an nZEB. This could support the application of a range of passive cooling techniques in buildings as well as the satisfaction of occupants, in coherence with EN15251 and a range of national and international analysis [31-35].

At present, the overheating phenomena in nZEB in Southern Europe is often attributed to some combination of air tightness, insulation, thermal mass, sometimes without offering in the analysis other fundamental information as: the presence or lack of solar protections, presence and quality of the connection to available passive cooling sources such as outdoor air in summer nights, soil, or sky vault at night, presence and quality of means for control of air velocity in the occupied spaces.

Finally, the nZEB uptake in Southern European countries is presently low and mostly poorly documented both in terms of energy performance and of thermal comfort and IEQ (see for comparison, the large monitoring project as EnOB in Germany [36]).

\subsection{Efficiency vs. renewables threshold}

EPBD requires European MS to first reducing energy needs for heating and cooling and in a second step to cover a significant fraction of those needs by energy from renewable sources on-site or nearby. In Switzerland, the authorisation to install summer air conditioning is subordinated to showing that the envelope is well designed to minimise energy needs for cooling (presence and effectiveness of solar shading with g-values optimised based on facade orientation, adequate insulation and thermal mass, as specified in SIA382), and detailed verification procedures are in place. Thus, energy efficiency is an effective policy tool and together with cost- effective energy savings they can play prime role in meeting energy, climate, and economic goals. However, many new constructions in the Southern Europe fail to take up ultra EE and renewable energy measures that are cost-effective. Investments in building renewable energy technologies seem sometimes easier to implement and communicate to occupants, investors and media. There is evidence that some building owners invest and lean towards RES due to the legal and construction barriers in investing in energy efficiency [28]. On the other side, the European recommendations for nZEB advise to include a share of renewable energy production on site (including the renewable share of heat pumps) [2]. For example, the Romanian government imposes for nZEB that at least $10 \%$ of energy is produced from renewable sources, according to the government ordinance No. 13/2016. But in dense urban areas, renewable energy sources (solar, imported biomass, etc.) have limitations regarding solar access and pollution associated with burning of biomass. For example, $70 \%$ of particulate emissions in Brussels are due to biomass burning [37]; similar problems with air pollution from biomass burning is reported in Pianura Padana, Italy and more generally described by the European Environmental Agency. Thus the optimal balance between the minimum threshold performance for $\mathrm{EE}$ and the renewables onsite production share for nZEB remains a challenge. The impact of these parameters varies strongly depending on energy cost, legal, environmental and construction barriers and requires long term vision that would help overcome these challenges.

\subsection{Construction quality}

nZEB require high construction quality through new construction technologies, sometimes high-tech components, specialised competences. To achieve nZEB levels, the use of energy efficient technologies and materials is necessary. These technologies and materials must respond to the requirements of the nZEB and satisfy the nZEB market demand. In most Mediterranean countries, there are barriers regarding the know-how of professionals and the number of architects and engineers that are able to deal with new technologies and standards [38]. For example, the Passive-On $[39,40]$ project published a guideline for designing and construction of Passive Houses in Southern Europe and considered the construction quality a serious challenge. The Passive House Regions with Renewable Energies project highlighted the importance of 
construction labor skills and their capacity of craftsmanship. Therefore, the SouthZEB project, that is an Intelligent Energy Europe (IEE) funded project, aimed to fill this gap and address the need to develop training schemes to professionals involved in nZEB building process, transferring successful practices and knowledge from front runners to target - Southern EU - countries that are less advanced in this area [41]. In order to reach a level of super insulation and airtight envelope, all suppliers of construction components and builders need to adapt integral nZEB construction practices. On the other side, the standard configuration and components of high efficient buildings is most of the time designed for heating dominated climates. For example, certified high performance windows are not offered as standard with (a choice of) integrated (or easy to integrate) external mobile shading. This should be changed in order to correctly reflect the needs and challenges of summer comfort in warm countries. The details of Passive House construction depend on the local climate, the shape and orientation of the building layout, the shading situation, etc. Therefore, it is crucial to determine the expected construction quality in each individual nZEB by assessing climate specific requirements and the local socioeconomic and technical limitations of construction market (labor, suppliers, producers, architects and building service engineers).

Finally, we discussed the five technical and societal challenges that need to be addressed for nZEBs in Southern Europe. Our study goes further in analysing the situation in Southern European countries regarding energy efficient new construction and refurbishment of existing buildings. Europe's ambitious targets and the above mentioned barriers make it difficult for many Southern European member states to step up to this policy plate. Today a limited number of nZEB are properly constructed and a very small part of the existing building stock is renovated every year. The actual technical and social barriers for nZEB implementation need to be identified through a cross comparative overview in order to find solutions to shift the identified barriers into opportunities and appropriate handlers for future development.

\section{Different approaches and barriers to implement nZEB in Southern Europe}

Following the challenges, we present the results of interviewing national experts in the seven investigated countries namely, Cyprus, France, Greece, Italy, Portugal, Romania and Spain, for which we could have access to representative information and insights. The meta-analysis is summarized in Table 2 providing a summary of nZEB status in Southern Europe. The following sections, present valuable and representative findings on the implementation approaches of nZEB. The complete results are presented and can be found in the final extended study report [42]. Then, we summarize the common barriers found in the 7 Southern Member EU States.

\subsection{Cyprus}

- The climate of Cyprus can be described as intense Mediterranean with hot dry summers from mid-May to mid-September with temperatures rising as high as $40^{\circ} \mathrm{C}$. Cyprus has changeable mild winters from November to mid-March, separated by short autumn and spring seasons with rapid changes of weather (see Fig. 4).

- The actual PE consumption for space heating for residential buildings in Cyprus is nearly twice the PE consumption for space cooling [44]. Experience, with energy performance certificates, shows that a heating demand performance level of $5 \mathrm{kWh} / \mathrm{m}^{2}$.a is possible to achieve.

- The nZEB concept introduced by the EPBD recast in 2010 provides a major challenge for Cyprus. Considering the fact that the first legislation regarding the energy performance of buildings (first introduced in 2007) and the Energy Performance Certification (EPC) of buildings (introduced in 2010) is relatively new [45].

- Retrofitting towards nZEB is practically non-existent, due to the high initial investment costs compared to the actual savings in energy costs in relation to the building's lifetime [46]. This makes such an investment financially infeasible for a private investor. Therefore, the costs for retrofitting towards nZEB were subsidized by the state.

- Despite a few drawbacks, the legislation and regulations regarding the nZEB in Cyprus are quite firm and on the right track. However, no legislation or regulations exist regarding the thermal comfort in buildings. The majority of construction engineers take into consideration the ASHRAE 55 standard whenever needed. Most of the time, no strict thermal comfort calculations are applied, neither in the standard building designs nor in nZEB.

- Given the fact that legislation and regulations regarding the energy performance of buildings calculation methodologies are relatively new, it is quite evident that practical experience and know how is still missing.

- Currently, the main problems are related to poor application of thermal insulation, humidity condensation and mold growth, airtightness issues and integration of renewables, especially in combined systems.

\subsection{France}

- France dominant climate regarding the Köppen-Geiger classification is mainly temperate and more especially classified as fully humid with warm summer (Cfb). The Mediterranean Sea area present low precipitations and hot summer (Csa) or warm summer (Csb). The French building standard divides the country into three main zones for winter (heating period): $\mathrm{H} 1, \mathrm{H} 2$ and $\mathrm{H} 3$, and four summer areas (non-heating period): $\mathrm{a}, \mathrm{b}, \mathrm{c}$ and $\mathrm{d}$ (see Fig. 5).

- France is facing a paradigm shift; moving from a pure energy approach with the RT2012 to an environmental assessment approach with Life Cycle Assessment (LCA) for the new building thermal regulation entitled RE2018 and RE2020.

- RE2018 promotes Positive Energy Buildings (BEPOS Bâtiment à énergie positive), targeting all building consumptions (energy use, including electrical households, computers etc. and not just 'conventional' consumption), and will strive to balance building energy consumption from non-renewable resources with from renewable energy resources (future energy mix, including renewable electricity) [48].

- The new regulations sets a standard for Low Carbon Buildings, taking into account the environmental impact of building material selection, construction and operation, including energy systems, greenhouse gases emissions also considering transport means used to access the building.. This both approaches allow defining a label $\mathrm{E}+\mathrm{C}-$ (Energy positive and Low Carbon) several levels of graduation that is being tested.

- Designers should be committed in the way to passive cooling, playing on optimizing the bioclimatic design indicator entitled: Bbio, which addresses compactness, windows surfaces, orientation, thermal inertia, airtightness etc. Single-family and multiple-family dwellings should be designed without using 'active' cooling systems. [48].

- The French building thermal regulation RE2018 will be based on standard EN 15251 concerning the adaptive comfort and ISO 7730 standard with a focus on summer comfort.

- With the BEPOS label, French regulations seek to maximize the rate of onsite photovoltaic production. 
Summary of nearly Zero Energy Buildings status in Southern Europe.

\begin{tabular}{|c|c|c|c|c|c|c|c|}
\hline & Cyprus & France & Greece & Italy & Portugal & Romania & Spain \\
\hline \multicolumn{8}{|l|}{ Legislation } \\
\hline $\begin{array}{l}\text { Definition nZEB } \\
\text { available }\end{array}$ & $\begin{array}{l}\text { Yes National Plan is in } \\
\text { place }\end{array}$ & $\begin{array}{l}\text { Yes, with Positive } \\
\text { Energy Buildings and } \\
\text { Low Carbon label }\end{array}$ & $\begin{array}{l}\text { Not a concrete one (leg. } \\
4122 / 2013 \text { ) }\end{array}$ & yes & $\begin{array}{l}\text { yes, National Plan is in } \\
\text { place }\end{array}$ & $\begin{array}{l}\text { no, National Plan is } \\
\text { under development }{ }^{\mathrm{f}}\end{array}$ & $\begin{array}{l}\text { no, under development } \\
\text { foreseen } 2108\end{array}$ \\
\hline Min threshold set & Yes & Yes & no & $\begin{array}{l}\text { Yes; Not explicitly in } \\
\text { term of kWh/m } \mathrm{m}^{2} \text {; } \\
\text { primary energy should } \\
\text { be lower than in the } \\
\text { baseline building; } \\
\text { hence it depends on } \\
\mathrm{S} / \mathrm{V} \text {, window/wall ratio } \\
\text { and other factors }\end{array}$ & no & no & no \\
\hline $\begin{array}{l}\text { Subsidy Retrofitting } \\
\text { towards nZEB }\end{array}$ & yes $(75 \% \max 25,000 €)$ & $\begin{array}{l}\text { No } \\
\text { (Only credit tax per } \\
\text { action } 30 \% \text {, max } \\
8000 € / \text { an.person) } \\
\text { replacement of } \\
\text { windows, shutters, } \\
\text { doors, insulation of } \\
\text { walls, roofs/lofts, floor } \\
\text { and energetic systems }\end{array}$ & no & $\begin{array}{l}\text { Yes. For retrofit of } \\
\text { public buildings } \\
\text { satisfying nZEB target, } \\
\text { up to } 75 \% \text { of } \\
\text { investment costs; for } \\
\text { retrofit of apartment } \\
\text { blocks achieving } \\
\text { relatively low energy } \\
\text { needs for heating and } \\
\text { cooling, } 75 \% \\
\text { (requirements are not } \\
\text { coincident with nZEB) }\end{array}$ & $\mathrm{n} / \mathrm{a}$ & $\mathrm{n} / \mathrm{a}$ & $\begin{array}{l}\text { yes, ex. projects FARO } \\
\text { REMOURBAN } \\
\text { Re_PublicZEB ECOCITY }\end{array}$ \\
\hline \multicolumn{8}{|l|}{ Min. Energy Efficiency } \\
\hline $\begin{array}{l}\text { PE use intensity } \\
\mathrm{kWh} / \mathrm{m}^{2} . \mathrm{a}\end{array}$ & $\begin{array}{l}100^{\mathrm{a}} \\
125^{\mathrm{b}}\end{array}$ & $70-110$ & no & $\begin{array}{l}\text { Not explicitly in term } \\
\text { of } \mathrm{kWh} / \mathrm{m}^{2} ; \text { it should } \\
\text { be lower than the } \\
\text { baseline building; }\end{array}$ & no & no & no \\
\hline $\begin{array}{l}\text { Min. perf. threshold } \\
\text { heating demand } \\
\left(\mathrm{kWh} / \mathrm{m}^{2} \mathrm{a}\right)\end{array}$ & $15^{\mathrm{a}}$ & $\max 15$ for $n Z E B^{c}$ & no & $\begin{array}{l}\text { Not explicitly in term } \\
\text { of } \mathrm{kWh} / \mathrm{m}^{2} ; \text { it should } \\
\text { be lower than the } \\
\text { baseline building; }\end{array}$ & no & no & no \\
\hline $\begin{array}{l}\text { Min. perf. threshold } \\
\text { cooling demand } \\
\left(\mathrm{kWh} / \mathrm{m}^{2} \cdot \mathrm{a}\right)\end{array}$ & No & $\begin{array}{l}\text { Temp. not below } 26^{\circ} \mathrm{C} \\
\text { for air-conditioned } \\
\text { buildings }(\mathrm{R} 131-29 \text { of } \\
\left.\text { law } \mathrm{n}^{\circ} 2007-363\right)^{\mathrm{c}}\end{array}$ & no & $\begin{array}{l}\text { Not explicitly in term } \\
\text { of } \mathrm{kWh} / \mathrm{m}^{2} ; \text { it should } \\
\text { be lower than the } \\
\text { baseline building; }\end{array}$ & no & no & no \\
\hline Life Cycle Assessment & no & yes & no & no & no & no & no \\
\hline $\mathrm{CO}_{2}$ & no & $\begin{array}{l}\text { yes, } \\
\text { building + operationg }\end{array}$ & no & no & no & no & no \\
\hline Airtightness & No & yes & no & no & no & no & no \\
\hline \multicolumn{8}{|l|}{ Heating Cooling Balance } \\
\hline $\begin{array}{l}\text { Natural ventilation } \\
\text { possible }\end{array}$ & $\begin{array}{l}\text { yes, } \\
\text { not taken into account } \\
\text { in calculations. Not } \\
\text { suitable in the south } \\
\text { coast due to excess } \\
\text { humidity levels }\end{array}$ & $\begin{array}{l}\text { yes, even obliged } \\
\text { passive cooling using } \\
\text { optimizing Bbio }{ }^{\mathrm{d}, \mathrm{h}}\end{array}$ & no defined yet & yes & yes & no defined yet & $\begin{array}{l}\text { yes, but not in } \\
\text { Southern Spain }\end{array}$ \\
\hline $\begin{array}{l}\text { Technical System Min. } \\
\text { performance } \\
\text { requirements }\end{array}$ & $\begin{array}{l}\text { Boilers 90\% Heat } \\
\text { pumps SCOP } 4.6 \text { SEER } \\
6.1\end{array}$ & $\begin{array}{l}\text { According to the EU } \\
\text { Directive Energy } \\
\text { related Products } \\
\text { (2009/125/CE) }\end{array}$ & no defined yet & & yes & & \\
\hline
\end{tabular}




\begin{tabular}{|c|c|c|c|c|c|c|c|}
\hline & Cyprus & France & Greece & Italy & Portugal & Romania & Spain \\
\hline \multicolumn{8}{|c|}{ Thermal Comfort Limits } \\
\hline Climate & 1 & H1a & A & A & 1 & 1 & $\alpha 3$ \\
\hline \multirow[t]{5}{*}{ Zones } & 2 & H1b & B & B & 2 & 2 & A3, A4 \\
\hline & 43 & $\mathrm{H} 1 \mathrm{c}$ & C & C & 3 & 3 & B3, B4 \\
\hline & 4 & $\mathrm{H} 2 \mathrm{~b}$ & $\mathrm{D}$ & $\mathrm{D}$ & & 4 & $\mathrm{C} 1, \mathrm{C} 2, \mathrm{C} 3, \mathrm{C} 4$ \\
\hline & & $\mathrm{H} 2 \mathrm{c}$ & & $\mathrm{E}$ & & & D1, D2, D3 \\
\hline & & H3 & & $\mathrm{F}$ & & & E1 \\
\hline Overheating risk & Yes & $\begin{array}{l}\text { Feedback in progress } \\
\text { for hotter climatic } \\
\text { zones }\end{array}$ & $\begin{array}{l}\text { There is high } \\
\text { overheating risk in case } \\
\text { of not proper design of } \\
\text { ventilation and } \\
\text { building insulation. }\end{array}$ & yes $(20,000 \text { deaths })^{*}, \mathrm{j}, \mathrm{k}$ & $\begin{array}{l}\text { yes, high risk (also high } \\
\text { winter mortality) }\end{array}$ & yes, pH es is over $5 \%$ & \\
\hline $\begin{array}{l}\text { Thermal comfort } \\
\text { Standard }\end{array}$ & No & $\begin{array}{l}\text { yes, adaptive comfort } \\
\text { model based on } \\
\text { EN15251 and ISO7730 }\end{array}$ & $\begin{array}{l}\text { yes, adaptive comfort } \\
\text { model based on } \\
\text { EN15251 }\end{array}$ & $\begin{array}{l}\text { yes, PMV and PPD from } \\
\text { ISO } 7730: 2005 \text {, and } \\
\text { prescriptions on } \\
\text { surface and interstitial } \\
\text { condensation from EN } \\
13788\end{array}$ & $\begin{array}{l}\text { yes, adaptive comfort } \\
\text { model based on } \\
\text { ASHRAE ST } 55 \text { AND EN } \\
15251\end{array}$ & $\begin{array}{l}\text { yes, ISO 7730, EN15251 } \\
\text { preliminary study done } \\
\text { on adaptive comfort }\end{array}$ & $\begin{array}{l}\text { yes, indoor limits based } \\
\text { on Fanger model and } \\
\text { ISO } 7730\end{array}$ \\
\hline \multicolumn{8}{|c|}{ Efficiency vs Renewable Threshold } \\
\hline RES (\%) & $25 \%$ & $\begin{array}{l}\text { For RT2012: minimum } \\
\text { of } 5 \mathrm{kWh} / \mathrm{m}^{2} . \text { year of } \\
\text { Renew. Energy } \\
\text { production of } \\
\text { maximum of } \\
12 \mathrm{kWh} / \mathrm{m}^{2} \text {.year PV } \\
\text { generation in order to } \\
\text { avoid To integrate PV } \\
\text { on energy wrecks }\end{array}$ & no & $\begin{array}{l}\text { Thermal energy } \\
\text { generation from } \\
\text { renewable sources } \\
\text { (>=50\% of energy use } \\
\text { for domestic hot water, } \\
>=50 \% \text { of energy use } \\
\text { for domestic hot water, } \\
\text { heating and cooling). } \\
\text { Electrical peak power } \\
\text { from renewable } \\
>=\mathrm{P}=2(\mathrm{~W} / \mathrm{m} 2)^{*} \mathrm{~S}\left(\mathrm{~m}^{2}\right) .{ }^{\mathrm{i}} \\
\text { All the above targets } \\
\text { are increased by } 10 \% \\
\text { for public buildings }\end{array}$ & no & & \\
\hline \multicolumn{8}{|l|}{ Construction Quality } \\
\hline available knowledge & low & medium & low & low & low & low & low \\
\hline
\end{tabular}

aResidential buildings.

${ }^{\mathrm{b}}$ Nonresidential buildings.

cFor cooling and heating.

'For cooling and heating.

e Unless noise restrictions.

${ }_{\mathrm{f}}^{\mathrm{f}}$ Numerical indicators are not exactly stated and they depends on several variables including technical viability, climate, type of construction, etc.

g Level "Carbon 1" overall impact of the building (building + operation) and Level "Carbon 2" impact of the construction only (non-operating).

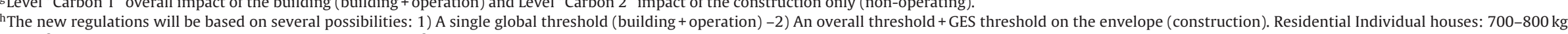

$\mathrm{CO}_{2} / \mathrm{m}^{2}$; Residential collective dwellings: $850-950 \mathrm{~kg} \mathrm{CO} / \mathrm{m}^{2}$. Thresholds differentiated according to energy.

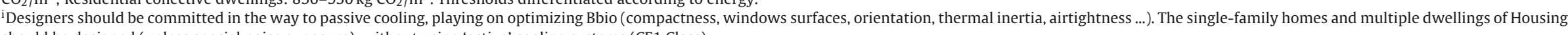

should be designed (unless special noise exposure), without using 'active' cooling systems (CE1 Class).

${ }^{\mathrm{i}}$ The installed renewables peak power should be higher than $\mathrm{P}=2\left[\mathrm{~W} / \mathrm{m}^{2}\right] \cdot S\left[\mathrm{~m}^{2}\right]$ where $S$ is the area of the footprint of the building.

${ }^{\mathrm{k}}$ The health consequences of the combination of high temperature and low quality building envelopes were quite heavy with 20,000 deaths in summer 2003 [52] 


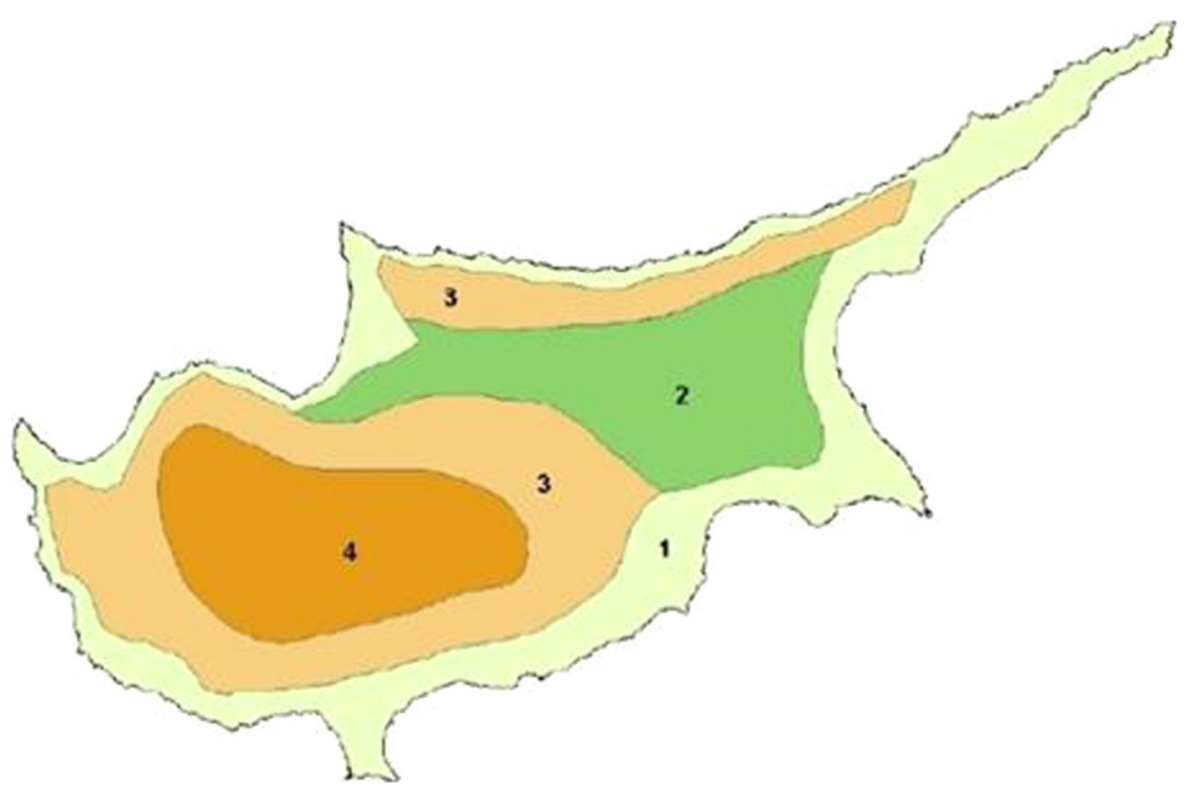

Fig. 4. Climatic Zones of Cyprus ( 1 - coastal zone, 2 - inland zone, 3 - semi-mountains zone, 4 - mountainous zone) [43].

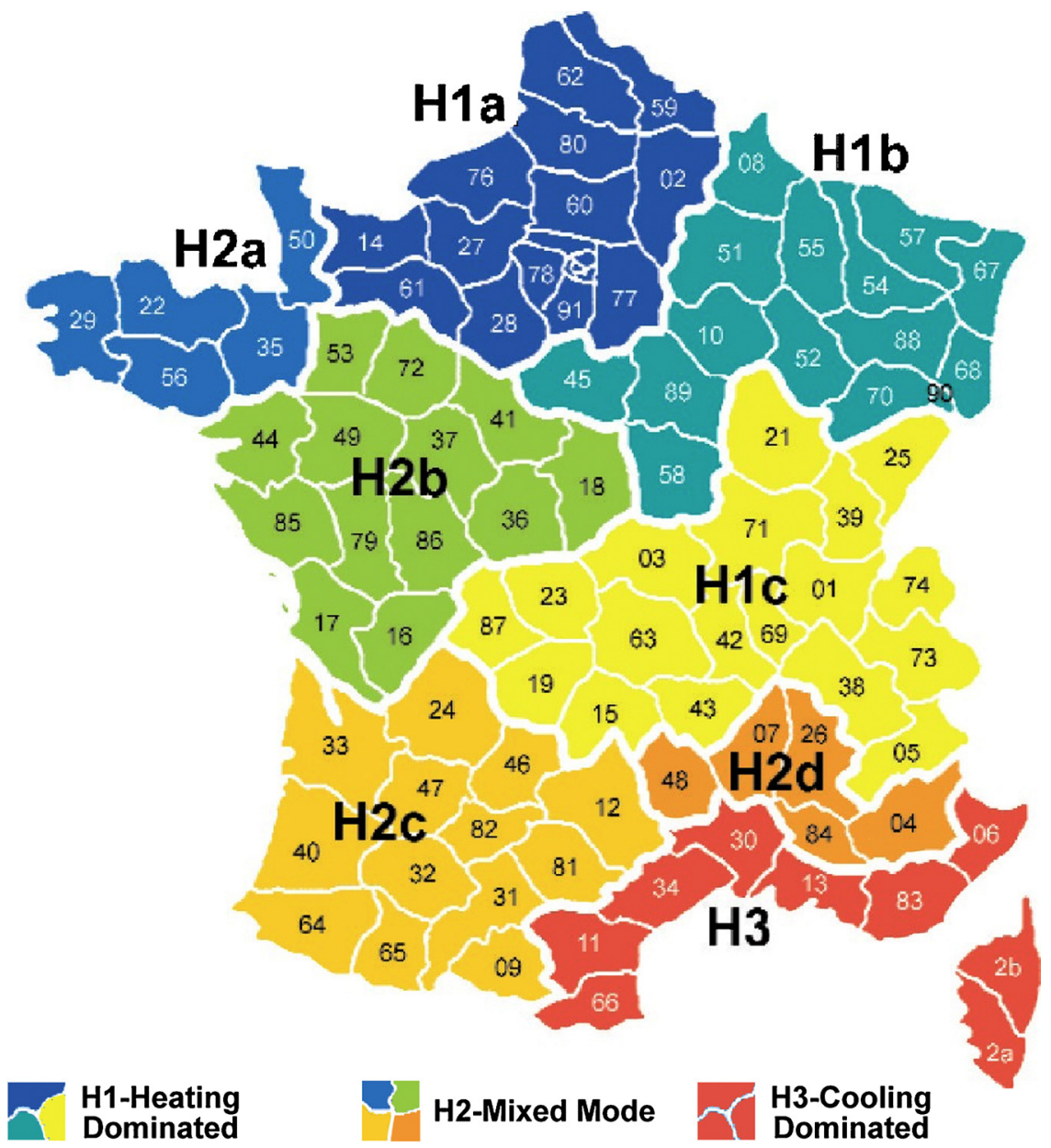

Fig. 5. Climatic zones of France based on cooling or heating or cooling and heating dominance [47].

3.3. Greece

- Based on the Greek Regulation for Energy Efficiency of Buildings, issued as the Ministerial Decision Official Gazette Bulletin
B' 407/09-04-2010 4 different climate zones (A, B, C and D) are defined based on heating degree days (HDD) dividing the country in 4 regions. Climate Zone A corresponds to regions in South Greece, whereas Climate Zone D to regions in Northern Greece. 


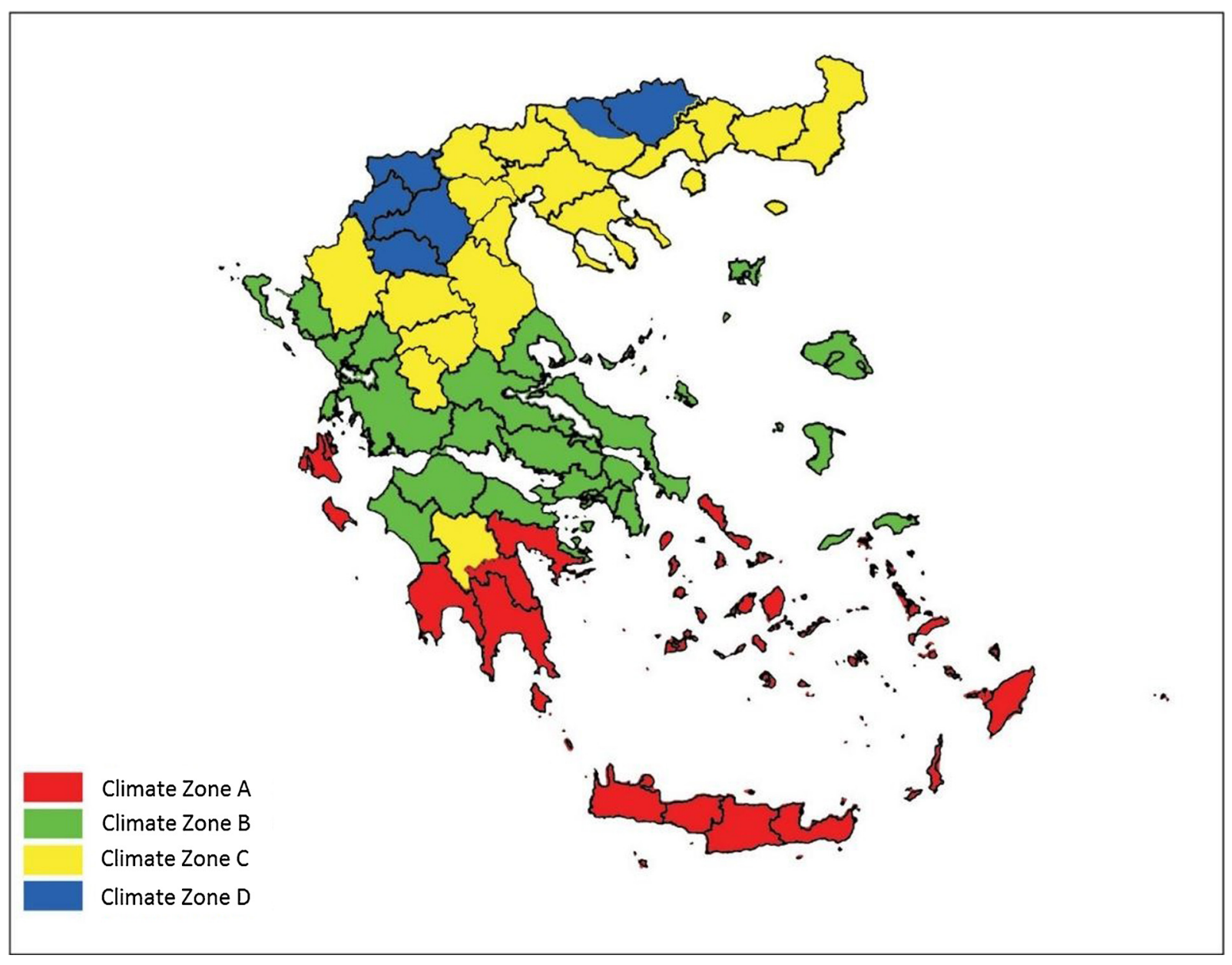

Fig. 6. Climate zones in Greece [49].

The rest of the regions are classified respectively to Climate Zone B and C. Fig. 6 presents the climate zones in Greece [49].

- The current status of nZEB adaptation in Greece is at an early stage. So far no performance thresholds and concrete definitions for nZEB are set. In most of Greece, it is most likely that the heating demand is relative low in nZEB compared to the cooling demand.

- The minimum energy efficiency threshold regarding nZEB has not yet been defined either regarding end use or PE. Moreover, no thresholds have been defined for $\mathrm{CO}_{2}$ emissions.

- There is no record of nZEB renovations of the residential buildings in Greece.

- The guidelines for the construction and the full renovation of existing buildings are developed based on European standards. They are defined in the Regulation for Energy Efficiency of Buildings, which was issued in 2010 [50].

- Legislation on thermal comfort is based on the European standard EN 15251, which includes the adaptive comfort model for the design and construction of nZEB. The comfort levels set through legislation in Greece refer to the combination of temperature and relative humidity during summer and winter time. The levels are different based on the use and function of the building.

- Until now no indicators for the use of RES in nZEB are set in Greece. Solar energy is the most used and considered as the most effective RES technology. However, the main barrier for greater uptake in urban areas is cost and the lack of space for solar access; especially in multi-family buildings.

- A major concern for the development of nZEB in Greece is the construction quality, while the construction material market lacks high-tech components and new construction technologies. More importantly, building professionals lack the know-how of the design and construction of nZEB.

3.4. Italy

- In Italy, a nZEB is defined as a building which has a better performance (in terms of energy needs for heating and cooling, total PE demand - RES - ...) than a baseline (virtual) building, which has the same shape, function, window/wall ratio and specified baseline properties (e.g. U value, g-value, ...).

- Some of the set properties of the baseline building (e.g. U-value) depend on surface-to-volume, so there is no explicit fixed value in $\mathrm{kWh} /\left(\mathrm{m}^{2}\right.$ a) for being classified as an nZEB. The baseline $\mathrm{U}$-values are higher than those recommended for $\mathrm{pH}$ certification $\left(0.15 \mathrm{~W} / \mathrm{m}^{2} \mathrm{~K}\right)$ and there is no explicit requirement on air-tightness. In general, the baseline building results to have energy needs for heating higher than a $\mathrm{pH}$ [21].

- The requirements for a retrofitted building to be labeled as nZEB are essentially the same as for a new building according to the Decreto 26 giugno 2015. Night ventilation during summer is generally an effective cooling strategy in the Italian climates, while external temperature is relatively low. Residential buildings in rural and quiet urban areas can rely on natural ventilation, which could be ameliorated by openings and windows design. However, in part of the urban areas, due to noise and pollution, nocturnal natural ventilation in residential buildings might need to be substituted by mechanical ventilation, thus requiring a sizing of the ventilation system to achieve higher $\mathrm{ACH}$ that would be required for winter alone. Tertiary buildings, not occupied at night, might 
profit in summer and mid-seasons of natural night ventilation to evacuate solar and internal gains irrespective of their location, with the addition of some simple anti-intrusion protections at windows.

- The risk of overheating might be relevant throughout the country for newly built nZEB in case their energy concept would be simplistically borrowed from northern design experience and no night ventilation (or other connection to cool sources) is applied. Nevertheless large improvements in the ability of the building fabric to decouple interior from exterior conditions is highly needed. The health consequences of the combination of high temperature and low quality building envelopes are quite heavy [52-54].

- The energy needs for cooling are expected to grow in the coming decades due to climate change, unless significant improvements of the envelope of existing buildings and passive cooling measures for buildings and cities are applied [55-57]; this increase in energy needs for cooling is even expected in high performance buildings [35].

- Small and Medium Enterprises (SMEs) working in the Architectural, Engineering and Construction (AEC) industry in Italy cannot sustain very high capital investments; they have difficulties to access loans, have low technological expertise and do not strive towards internationalisation or technological innovation. Often architects and building engineers do not have a comprehensive understanding of modern adaptations and improvements of passive techniques and available innovative technologies they could apply in their building designs in relation to climatic classification (Fig. 7) [58].

\subsection{Portugal}

- The Portuguese regulation [59] has been adapted with the EPBD recast updates and presents a definition for nZEB in which an nZEB is a building that uses the cost-optimal solutions for the envelope and where the renewable energy harvested on-site or nearby is used to fulfil a significant part of the remaining energy needs.

- The definition of nZEB is not yet complete, the current regulation does not present any specific requirements for nZEB rehabilitation and there are no specific renovations towards nZEB.

- The pH Standard is not considered to become a reference in Portugal mainly because of its dependence on mechanical ventilation with heat recovery and high airtightness of the building envelope. The mild winters in a significant portion of the country, makes the investments in the $\mathrm{pH}$ requirements most of the times not cost-effective when considering heating costs only.

- Recent studies documenting the thermal performance of vernacular architecture in Portugal [60] and the overheating risk using the heating gains coefficient [61] as provided in the current thermal regulation [59], demonstrate that it is possible to achieve indoor thermal comfort by passive means and by the occupants' action during the summer period (see Fig. 8).

- The National Laboratory of Civil Engineering (LNEC) has developed an adaptive model of thermal comfort [63], which is an adaptation to the Portuguese context of the model specified in the ASHRAE Standard 55 [64] and EN 15251 [15].

- Occupants may tolerate (under wider comfort conditions) broader temperature ranges than those indicated in current standards, in particular in the heating season; the external temperature has strong influence on the occupants' thermal perception/sensation [65].

- Portugal is consistently identified as the country with the highest number of excess winter mortality in Europe [66,67].

- In the case of existing buildings, the transition to nZEB introduces additional constraints for the control of overheating risks. The solar orientation, the organization of the internal spaces and the window-to-floor area ratio are difficult or impossible to optimize in Portuguese cities limiting the scope of passive building design elements to work with.

- Portugal's PV sector is mainly driven by small installations, namely micro and mini installations. Since 2014, significant cuts were made in the feed-in tariff (FIT) for these types of installations, and the aim is to bring micro and mini generation FIT prices down to market prices. The main incentive is now given to the self-consumption regime, by the elimination of almost any bureaucracy to allow its installation.

- The climatic conditions, the economic constraints and the cultural habits, all point to the use of low tech instead of high tech nZEB solutions.

- The nZEB integrated project delivery approach and the knowledge of the exigencies of designing a nZEB is not common for architects and engineers in Portugal which will lead in many cases to inefficient solutions, non-optimized buildings and higher costs due to extra measures for integration of energy efficiency measures and renewable energy systems [68].

\subsection{Romania}

- Many southern regions of Romania can be associated with the Southern climate of Europe (Fig. 9). The temperate-continental climate of Romania consists of hot summers and relatively cold winters $[69,70]$.

- There is no minimum threshold specified for the heating, cooling demand or total energy demand for nZEB in Romania [71]. There is no nZEB renovation in Romania so far.

- Nearly zero heating demand is difficult to reach in most Romanian cities. In Romania, high airtightness values make sense in order to reduce heat losses associated with air changes, losses which can reach between 15 and 50\% of total losses in conventional buildings [72].

- The standard ISO 7730-2005 is presently adopted in Romania [73]. It contains the Fanger model PMV-PPD. Supplementary to ISO 7730; EN 15251 describes shortly the concept of adaptive control (for HVAC system) and also establishes the equations of checking the indoor temperature in conditions of natural ventilation. Preliminary studies on the adaptive comfort model have already been done in Romania [73], including the overheating risk for $\mathrm{pH}$ es, which is over $5 \%$ in free-running conditions of summer in Bucharest area [74].

- The Romanian supply chain for construction material and products market is still highly fragmented with different despaired product performance categories and qualities, which makes it difficult for building engineers to select high quality nZEB components. A local standardization of the products quality is needed to break up some monopolistic practices in combination with access to high quality products at an affordable price.

\subsection{Spain}

- The definition and regulation for nZEB in Spain are expected to come out in 2018.According to the last modification of Spanish regulation [75], every building which satisfies the minimum requirements of the current technical building code is considered nZEB. However, the upcoming update of the Spanish technical building code (CTE) has not been published yet and for now, there is only a draft of the future building energy indicators [76].

- One of the major challenges of nZEB implementation in Spain is the large differences between the climate zones. This requires a set of indicators that permit evaluating different approaches to achieve nZEB in Spain's varying climate. Spain is a country that includes many different climatic zones (see Fig. 10). Depending 


\section{Legenda}

$G G=$ gradi giorno

$\square$ Zona A GG $\leq 600$

Zona B 601 $\leq \mathrm{GG} \leq 900$

(Crotone. Agrogento, Catania, Siracuso, Trapani, Messina, ...)

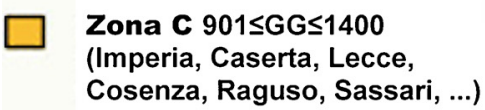

Cosenza, Raguso, Sassari, ...)

Zona D $1401 \leq G G \leq 2100$
(La Spezia, Forli, Isernia,

Foggia, Caltanissetta, Nuoro ...)

Zona E $2101 \leq G G \leq 3000$

(Trieste, Acosta, Sondrio, Bolzano

Udine, Rimini, Frosinone, Enna ...)

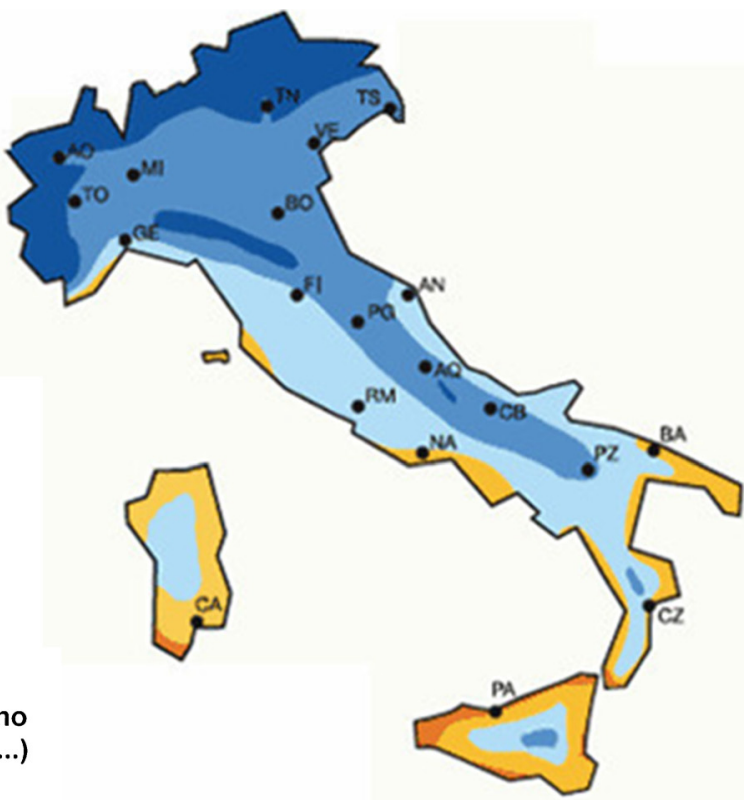

Zona F GG $\leq 3001$

(Cuneo, Belluno ...)

Fig. 7. Classification of winter climate in six zones by Italian legislation (D.P.R. 412/93) GG = Gradi Giorno or Heating Degree Days (HDD) [51].

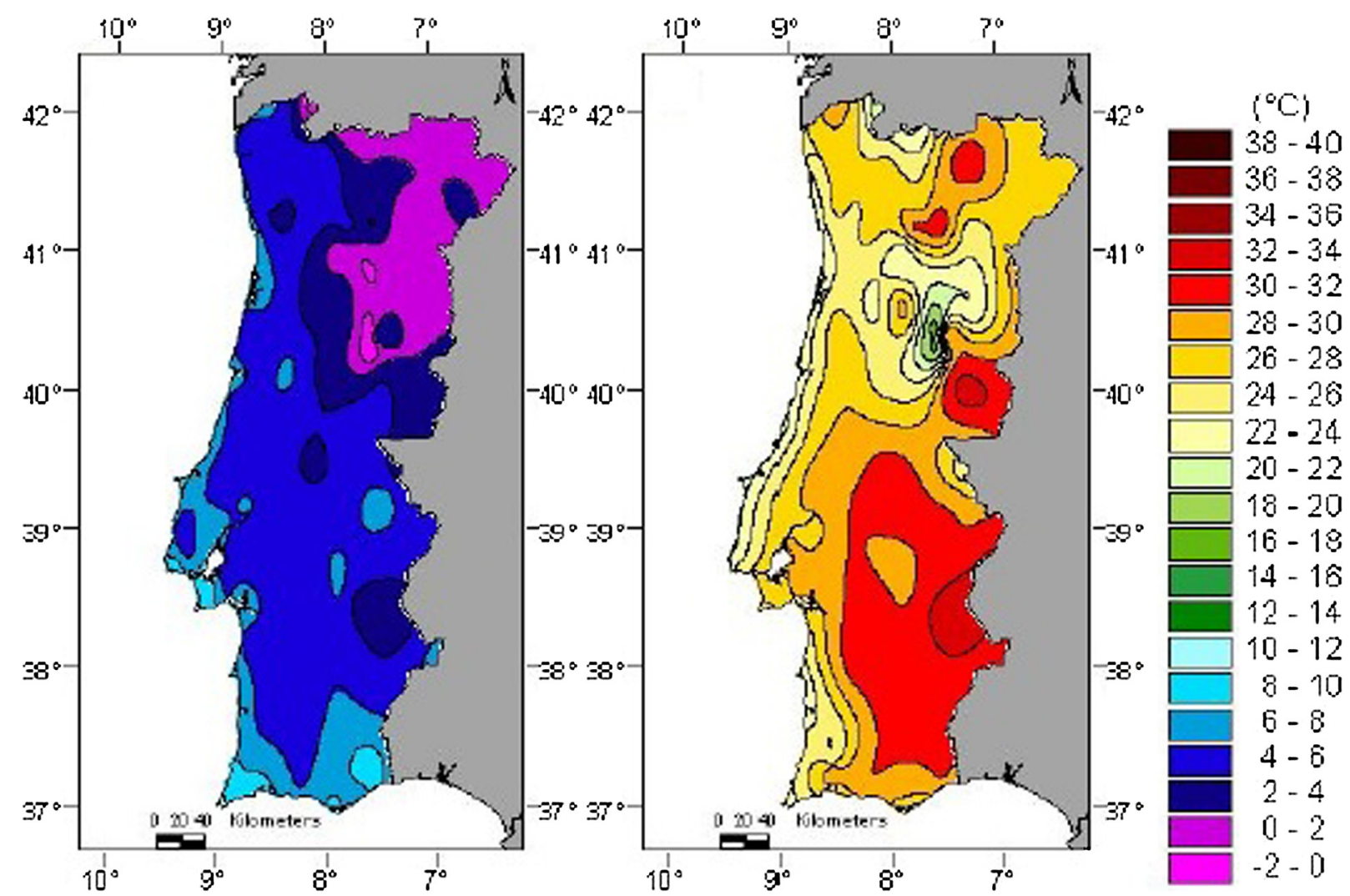

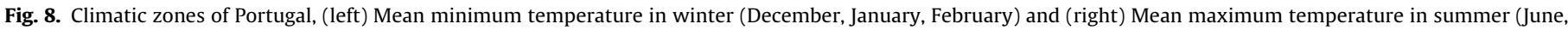
July, August). Data from 1961 to 1990 observations [62].

on the altitude, the climate applied to particular towns may differ from the climate of the region.

- The barriers of nZEB implementation are due to the slow development of a definition and the difficult economic market situation.
- At present, the thermal comfort in Spanish buildings is based on Fanger's PMV-PPD model [77] and it does not consider the adaptive potential of EN15251. The risk of overheating in Southern Spain is high, mainly because the night temperatures during most part of summer are not low enough for natural ventilation [78]. 


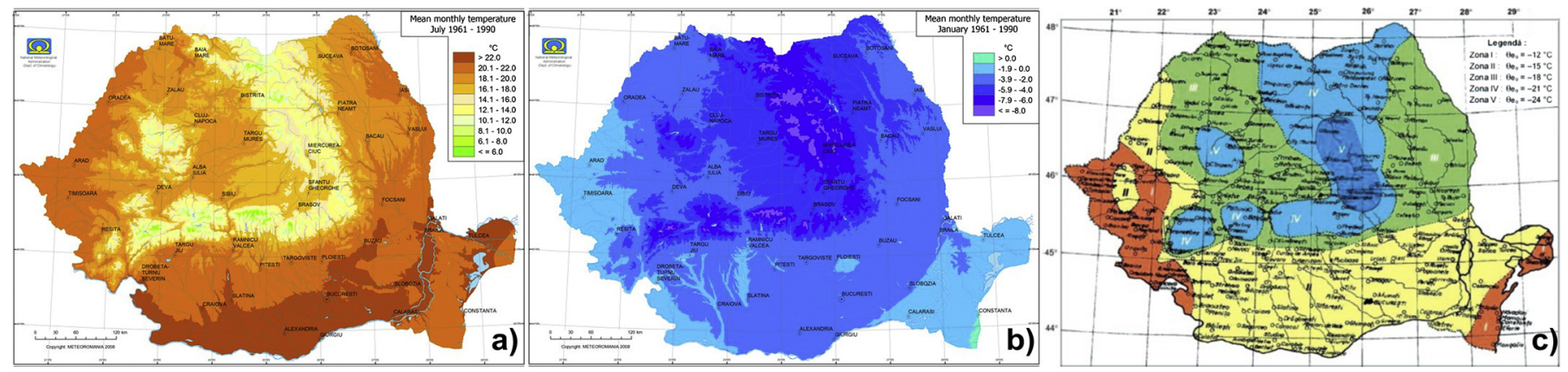

Fig. 9. Averaged temperature distributions on the territory of Romania: a) Summer season; b) winter season; c) standard climatic zoning (I-V) [69].

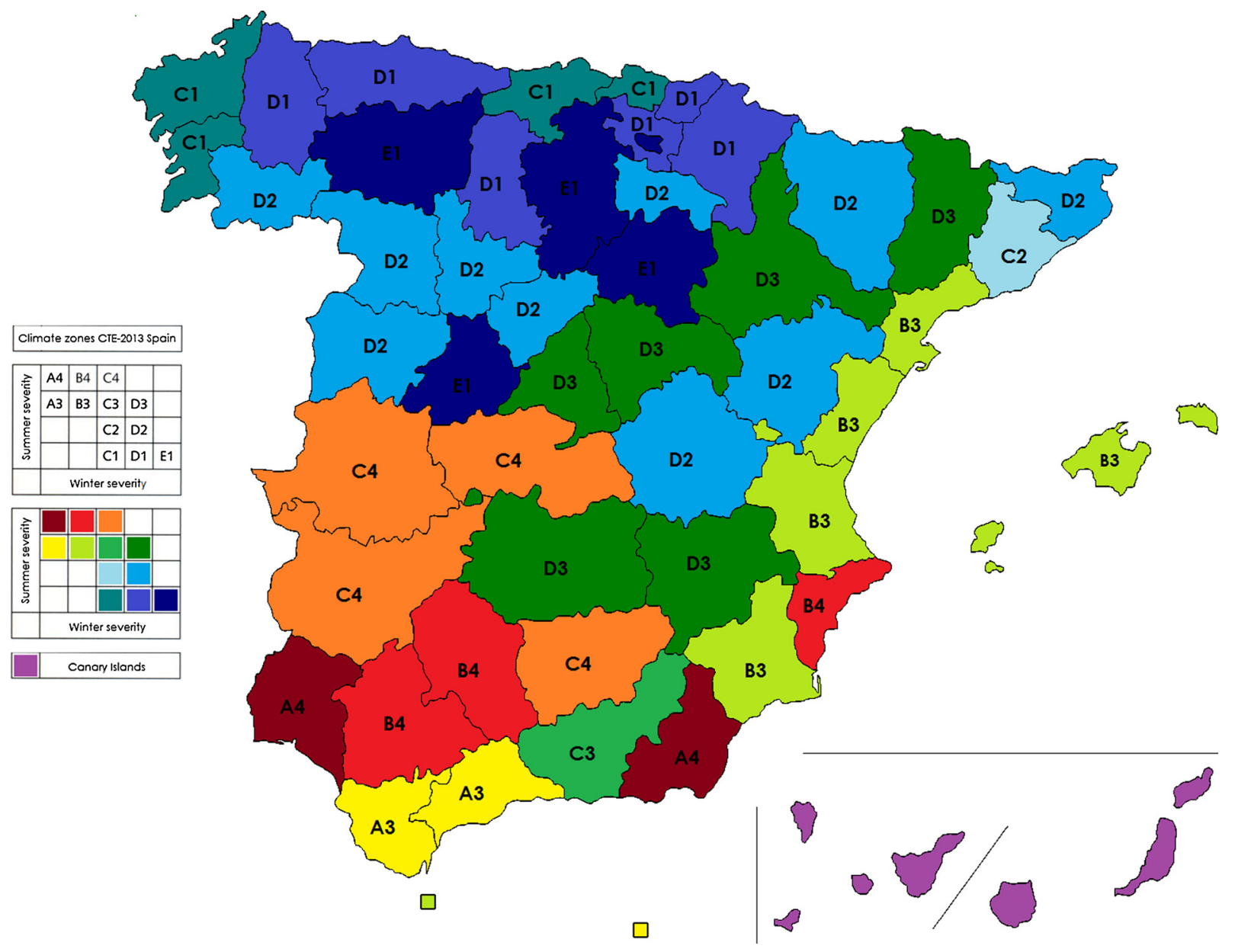

Fig. 10. Spanish climate zones (map based on data obtained from CTE DB-HE of 2013) [75].

- Regarding energy building renovations, large socio-economic barriers are limiting the progress of deep renovations in residential sector. nZEB deep renovations are technically feasible and following examples are a proof for that: FARO REMOURBAN project in Valladolid [79], Re_PublicZEB in Catalonia [80] and ECOCITY in Vitoria-Gasteiz [81].

\subsection{Barriers of nZEB implementation in Southern Europe}

The 2016 European Energy Efficiency Directive requires that MS draw up national plans for increasing the number of nZEB and develop policies and take measures to stimulate the transformation of buildings that are refurbished into nZEB. According to the review results these are perceived as challenging targets and many MS are finding it difficult to match them. Southern European countries have their own technical and societal barriers, beside the economic barriers including fuel poverty that lead to a low implementation rate of nZEB and the status of high performance renovation is poorly documented [4,82-84]. There are strong barriers for nZEB in the residential sector that play a significant role in the housing sector. We highlight below the most arduous barriers identified from the study.

- The first common barrier that appeared from the study is related to the particularity of geography and climate in Southern Europe. The climate in Southern European cities presents hot summer, intense solar radiation, recurrent heat waves and exacerbation of urban heat island effect due to climate change. The apparent 
temperature thresholds and solar radiation in the Mediterranean cities are high. Design and construction practice has generally failed in the last decades to merge the new construction materials and components with the consolidated bioclimatic concepts of solar shading, thermal mass and night ventilation. Design and construction skills of bioclimatic design have been mostly lost and summer comfort is objectively difficult to evaluate quantitatively and to grasp intuitively due to its intrinsically dynamic features [85]. The potential and limits of passive strategies are often either overlooked or overestimated, with a general lack of objective assessment and optimised design. Poor design, construction, documentation and management are widespread in the standard construction practices of last decades and are not frequent still today. As a result, many residential and service sector buildings are frequently experiencing summer conditions, which are out of the comfort ranges, whatever comfort model is chosen [86,20], and/or suffer of other discomfort issues (glare from unprotected transparent surfaces, noise form air conditioning equipment,... ). This situation decreases the overall wellbeing and productivity of building occupants and increases their vulnerability to health problems $[52,87,88]$.nZEB in Southern Europe need to be adaptive buildings addressing both heating and cooling seasons more properly. The lack of finding geographically and climatic (geoclimatic) adapted and performance proofed concepts for nZEB in Southern Europe makes it very difficult to define primary energy thresholds for nZEB and minimum comfort performance requirements. The correlation between climate change and overheating risk should be further investigated $[89,35]$. Well-being and comfort should be the primary goals of building design but quite often, contrary to energy performances, are not explicitly and objectively specified in the design scope and hence fail to be correctly addressed in the design and construction phases. Without clarifying the above issues, performance of new construction and deep renovation will remain vague and ineffective.

- A second common barrier that appeared from the study is methodological. The methodology used to implement nZEB in Southern Europe is partly related to inappropriate use of rules of thumb or calculation-based design approaches with little feedback from performance monitoring. Most building professionals and researchers in Southern Europe overly rely on steady state simulation tools to address the design and construction of nZEB and have no links to laboratory or field measurements or real performance monitoring. Based on the interviews feedback, there is a perception among professionals and building owners/occupants in Southern countries that static or semi-static calculations based on EN standards (e.g. those generally used for drafting EPCs) represent the real consumption of buildings. In fact, EPC levels granted to buildings are just made for benchmarking purposes and quality assurance; however, they do not represent the real expected building performance and EUI. At the same time, there are very little monitored case studies for nZEB in Southern Europe that assess the dynamic behaviour of buildings in relation to energy use for active space heating and cooling and passive cooling. The EN15603:2008 and the other EN standards allow for the calculation of energy needs for heating, cooling and hot water and energy use for lighting and ventilation of new building and retrofits. The relatively simple use of stationary or semi stationary calculation tools makes it seem possible to achieve nZEB in Southern European cities. However, those calculation tools are often used as design tools with high confidence of the building performance after construction $[85,86]$ without an estimate about the degree of uncertainty deriving from uncertainties in the input values (outdoor weather file often outdated or not pertaining the exact location under study, building material properties, effectiveness of controls, effect of occupants behaviour, approximation of the software algorithms and of the geometrical description of the building,...). Comparison of the monitoring results shows that some nZEB do not perform adequately in terms of summer comfort [89] similarly to many of the conventionally designed buildings. Interpretation offered for the discomfort experienced in part of the nZEB were pointing at different ventilation and shading control patterns by the occupants [90-92]. Even though Schnieders [93] found that in pH buildings "the peak heating and cooling loads where also less pronounced and internal temperature fluctuations were lower regardless of whether active cooling was applied" he also warned that "it is important to note that the differences in climates and the effects of individual building parameters are so large that a dedicated energy balance must be set up for every $\mathrm{pH}$. The use of standard values for different buildings is not appropriate" [93]. This supports the hypothesis that the energy gap and overheating risk are possibly related to theoretical design approaches that are based on an improper use of calculation methods with an overreliance on the numerical results without a critical view which includes an estimate of uncertainties. A better communication on the role of EPBD calculations and EPCs is further needed.

- Lastly, national and local authorities in Southern European countries often lack local governance and a national strategy to create an infrastructure for nZEB implementation. One of the main barriers to nZEB market uptake is the weak human infrastructure. By human infrastructure we mean:

i) local authority officials dealing with buildings permits and energy performance certification,

ii) building professionals/researchers dealing with the design and constructions process,

iii) and industrial stakeholders dealing with products manufacturing and supply.

In many cases, local authorities are not in contact with local research centres to deepen their understanding of nZEB and their implementation requirements. As a consequence, little effort has been done to provide local guidelines for nZEB procurement. The strong climate variation in some countries requires flexible and regional climate performance requirements for nZEB. For example, the heating and cooling balance in Northern Spain is not the same as in Southern Spain. For the nZEB definition, descriptive parameters should be clearly identified, but their mandatory target values should be carefully tuned to the individual climates. In this context, many local authorities are not prepared to lead this transition. Also many building professionals cannot lead the nZEB implementation process from design to construction to meet the expected market demand [58,92]. Even architects and engineers who opt to comply with the $\mathrm{pH}$ standard face serious challenges with implementation due to the lack of vocational training and capacity building for nZEB. There are several multidisciplinary actors that should be involved in nZEB implementation and not only engineers, adding to the complexity of the process. In many investigated cases, there are no national or regional strategies to empower consultation, builder's skills and construction services for new and renovated nZEB. Most contractors in the South are far away from nZEB best practices and technical construction accuracy. Finally, the construction industry is not prepared with experience and products to deliver and supply the expected market demand. The sustainability business is fundamentally based on local industrial infrastructure of systems, products and national energy mix. In relation to the first barrier, most national industries in Southern European countries, are, on average, not well positioned to cater for high-tech buildings requiring innovative products, systems and solutions aligned with the national energy mix and carbon emission reduction targets. So, overall, the top down legislation framework and targets 
set by the European Directives were insufficient to stimulate the development of a national and local bottom up environment of human and industrial infrastructure to carry out the transformation of building practices. The above difficulties and barriers should be successfully addressed as a prerequisite condition for allowing the construction of a successful set of new nZEBs and for achieving the deep renovation of the existing buildings stock in Southern European Countries, which form more than one third of the EU total building stock, [94].

\section{Discussion and conclusion}

After presenting the results of our meta-analysis above, we would proceed to discuss the outcomes of our research. In this section, we identify the key study findings and developed a series of recommendations towards a higher market uptake of nZEB in Southern European Countries for new construction and retrofits. The market of nZEB in Southern Europe is in the predevelopment phase. The next step of the market development process would be the take-off phase before the acceleration phase and finally reaching the stabilization phase. In order to balance the presented overview on the current state of implementation of nZEB and their technical and societal barriers, we present a group of recommendations. The recommendations can provides future perspective for policymakers, funding agencies (including the national banks and the European Investment Bank) and building stakeholders, with regard to the transition phases and development of nZEB. The following discussion highlights the key study findings and elaborates on the study strength, limitations and future work.

\subsection{Study findings}

Our assessment indicates that three main technical and societal barriers impede the market uptake of nZEB in Southern Europe. We think that the introduction of the EPBD, EPCs and the nZEB performance target and regulations happened fast for most Southern countries which did not manage to keep the pace to build up local knowledge and infrastructure, given the parallel budget restrictions under the Maastricht rules. This is an alarming conclusion, because if we add up to those barriers the financial barriers related to the cost-optimality, which are out of this study scope, we can confirm that the Southern European countries are likely not to be ready for an effective successful implementation of the nZEB target. Obviously, there is a lack of understanding of nZEB's performance in Southern Europe, disparity in the use of performance indicators, and the dependence on a virtual calculation approach that is not based on an experimental approach of building monitoring. As a consequence, there are no clear functional concepts of nZEB that can help to set up a definition and implementation strategy. The use of static calculation-based design approach is insufficient in a cooling and heating dominated region. However, we believe that the root cause of those barriers is the lack of sufficient funding of human infrastructure which is namely the:

i) procurement officials and technical staff in local authorities,

ii) building professionals/researchers and

iii) research and technical staff in industrial stakeholders in most Southern European countries.

Ironically, the European Union, the European Investment Bank and national governments in Southern Europe focus on supporting and financing the implementation of nZEB without focusing on the enforcing and enabling human infrastructure (problem root cause) that should understand and define nZEB's performance before carrying them out.

\subsection{Study recommendations}

In Southern Europe, the challenge of embracing the nZEB concept is technical, societal, and organizational before being economical. The nearly-zero energy target is a good idea to improve the IEQ and EE of new buildings and the existing building stock. According to our interviewed experts, Southern European MS are looking to embrace this target. However, the challenge remains on how to reach it. As part of this paper's scientific contribution, we classified and grouped a series of recommendations under five major topics. This includes suggestions for nZEB performance threshold in Southern Europe's MS.

\subsubsection{Technical development}

A prerequisite for any technical should be based on a common regional framework and terminology. Wwe recommend a systematic use of EN/ISO definitions of energy levels (see Fig. 2) in both technical and policy documents in order to facilitate the work and reduce costs of design and construction firms. MS should make clear and explicit requirements for low energy needs for heating and cooling in their national implementation of the nZEB concept. Reaching nZEB requires that we change our rules of thumb and design assumptions of the real potential of bioclimatic architecture and passive design in mixed-mode and cooling dominated climates. We need new and different concepts that are geoclimatically developed respecting climate sensitivity and avoiding overheating risks. This includes developing the definitions and performance requirements for nZEB in Southern Europe. As part of our research, we present in Table 3 some performance threshold suggestions for nZEB in Southern Europe's Member states. We suggest the minimum EE and RET production across the investigated countries. Table 3 lists the suggested performance thresholds based on the input provided by national experts. In complementarity with Table 3, we recommend using the adaptive comfort model EN 16798-1, formerly known as EN 15251, in all Southern Countries. We need to develop nZEBs that are energy efficient and also healthy, comfortable and that meet relevant IEQ requirements. We advise MS to continue developing national adaptive comfort requirements backed by field measurement and surveys in relation to fuel poverty. It is substantial to reach a consensus on the definition of nZEB for new and retrofit of existing buildings among Southern European member states.

According to Table 3, there is a disparity between the different suggested energy need thresholds mainly for cooling ranging from 5 to $100 \mathrm{kWh} / \mathrm{m}^{2}$.a. This means that the energy needs for cooling remain signifcant in Southern Europe. Therefore, we recommend predisposition elements for passive cooling systems or efficient active cooling systems and integrate them in the design as backup systems for extreme heat periods. With climate change, Southern Europe will be exposed to intense and longer heat waves. After having reduced solar and internal gains, integrating passive cooling systems, such as ground exchangers, evaporative cooling, night sky radiation or correctly sized efficient active cooling, in the current nZEB definition and design is better than avoiding it and leaving users to do it themselves. Potential and limits of passive cooling strategies should not be either overlooked or overestimated, but rather be subject to careful and uncertainty-conscious design and monitoring-based assessment, in order to objectively face the challenges created by climate change, dense urbanisation, noise pollution, air pollution and population ageing.

\subsubsection{Organizational - harmonizing and sharing}

We need to harmonise actions between Southern Countries. The advantage of Southern European countries is that they consider the knowledge transfer between the MS as a mean to cross many barriers associated with nZEB implementation. The creation 
Table 3

Suggestion for nZEB performance threshold in Southern Europe's Member States.

\begin{tabular}{|c|c|c|c|c|c|c|c|c|c|c|}
\hline \multirow[t]{2}{*}{ Country } & \multirow{2}{*}{$\begin{array}{l}\text { Climate } \\
\text { Zone }\end{array}$} & \multicolumn{2}{|l|}{ Min. Energy Efficiency } & \multirow{2}{*}{$\begin{array}{l}\text { Primary } \\
\text { Energy } \\
\mathrm{kWh} / \mathrm{m}^{2} \cdot \mathrm{a}\end{array}$} & \multirow{2}{*}{$\begin{array}{l}\text { RES } \\
\text { share }\end{array}$} & \multirow{2}{*}{$\begin{array}{l}\text { Summer } \\
\text { Climate } \\
\text { Cities }\end{array}$} & \multicolumn{2}{|c|}{ 2010-2015 } & \multirow[b]{2}{*}{ Latitude } & \multirow[b]{2}{*}{ Altitude } \\
\hline & & $\begin{array}{l}\text { Energy need for Cooling } \\
\mathrm{kWh} / \mathrm{m}^{2} . \mathrm{a}\end{array}$ & $\begin{array}{l}\text { Energy need for Heating } \\
\mathrm{kWh} / \mathrm{m}^{2} \cdot \mathrm{a}\end{array}$ & & & & $\begin{array}{l}\mathrm{CDD} \\
25^{\circ} \mathrm{C}\end{array}$ & $\begin{array}{l}\text { HDD } \\
20^{\circ} \mathrm{C}\end{array}$ & & \\
\hline & 1 & & & & & Larnaca & 125.7 & 1051 & $34.5^{\circ} \mathrm{N}$ & $26 \mathrm{~m}$ \\
\hline & 2 & & & & & Nicosia & 304.2 & 1253 & $35.1^{\circ} \mathrm{N}$ & $220 \mathrm{~m}$ \\
\hline \multirow[t]{5}{*}{ Cyprus } & 1 & $100-120$ & 15 & 100 & $30 \%$ & Paphos & 29.3 & 1039 & $34.8^{\circ} \mathrm{N}$ & $72 \mathrm{~m}$ \\
\hline & 4 & & & & & Prodromos & 8.5 & 2831 & $34.6^{\circ} \mathrm{N}$ & $1380 \mathrm{~m}$ \\
\hline & $\mathrm{H} 1 \mathrm{a}$ & & & & & Paris & 75 & 2294 & $48.8^{\circ} \mathrm{N}$ & $35 \mathrm{~m}$ \\
\hline & H1b & & & & & Strasbourg & 123 & 2843 & $48.5^{\circ} \mathrm{N}$ & $150 \mathrm{~m}$ \\
\hline & $\mathrm{H} 1 \mathrm{c}$ & & & & & Lyon & 155 & 2142 & $45.7^{\circ} \mathrm{N}$ & $200 \mathrm{~m}$ \\
\hline \multirow[t]{5}{*}{ France $^{\mathrm{a}}$} & $\mathrm{H} 2 \mathrm{~b}$ & $5-20$ & $5-20$ & 50 & $50 \%$ & Nantes & 57 & 2063 & $47.2^{\circ} \mathrm{N}$ & $26 \mathrm{~m}$ \\
\hline & $\mathrm{H} 2 \mathrm{c}$ & & & & & Toulouse & 158 & 1777 & $43.6^{\circ} \mathrm{N}$ & $150 \mathrm{~m}$ \\
\hline & H3 & & & & & Marsilia & 257 & 1381 & $43.2^{\circ} \mathrm{N}$ & $42 \mathrm{~m}$ \\
\hline & $\mathrm{D}$ & & & & & Kozani & 51 & 2844 & $40.3^{\circ} \mathrm{N}$ & $710 \mathrm{~m}$ \\
\hline & $\mathrm{C}$ & & & & & Thessaloniki & 135 & 2110 & $40.6^{\circ} \mathrm{N}$ & $7 \mathrm{~m}$ \\
\hline \multirow[t]{4}{*}{ Greece } & B & 80 & 80 & 100 & $25 \%$ & Athens & 228 & 1321 & $38^{\circ} \mathrm{N}$ & $194 \mathrm{~m}$ \\
\hline & A & & & & & Iraklion & 115 & 1064 & $35.3^{\circ} \mathrm{N}$ & $35 \mathrm{~m}$ \\
\hline & A & & & & & Lampedusa & 368 & 1060 & $35.3^{\circ} \mathrm{N}$ & $20 \mathrm{~m}$ \\
\hline & B & & & & & Palermo & 362 & 1570 & $38.1^{\circ} \mathrm{N}$ & $14 \mathrm{~m}$ \\
\hline \multirow[t]{5}{*}{ Italy } & $\mathrm{C}$ & 15 & 15 & 120 & $50 \%$ & Napoli & 336 & 1803 & $40.5^{\circ} \mathrm{N}$ & $72 \mathrm{~m}$ \\
\hline & $\mathrm{D}$ & & & & & Rome & 234 & 1405 & $41.9^{\circ} \mathrm{N}$ & $13 \mathrm{~m}$ \\
\hline & $\mathrm{E}$ & & & & & Milan & 168 & 2439 & $45.2^{\circ} \mathrm{N}$ & $121 \mathrm{~m}$ \\
\hline & $\mathrm{F}$ & & & & & Bolzano & 245 & 3552 & $46.5^{\circ} \mathrm{N}$ & $262 \mathrm{~m}$ \\
\hline & 1 & 0 & 30 & & & Porto & 27 & 1250 & $41.9^{\circ} \mathrm{Nx}$ & 94 \\
\hline \multirow[t]{4}{*}{ Portugal } & 2 & 15 & 40 & 33 & $50 \%$ & Lisbon & 61 & 1093 & $38.8^{\circ} \mathrm{N}$ & $114 \mathrm{~m}$ \\
\hline & 3 & 30 & 70 & & & Faro & 77 & 606 & $37^{\circ} \mathrm{N}$ & $72 \mathrm{~m}$ \\
\hline & 1 & & & & & Constanta & 151 & 2363 & $44.2^{\circ} \mathrm{N}$ & $40 \mathrm{~m}$ \\
\hline & 1 & & & & & Timisoara & 223 & 2595 & $43.2^{\circ} \mathrm{N}$ & $87 \mathrm{~m}$ \\
\hline \multirow[t]{4}{*}{ Romania } & 2 & 15 & 15 & 120 & $10 \%$ & Bucharest & 261 & 2633 & $44.4^{\circ} \mathrm{N}$ & $77 \mathrm{~m}$ \\
\hline & 3 & & & & & Cluj-Napoca & 134 & 2974 & $46.7^{\circ} \mathrm{N}$ & $380 \mathrm{~m}$ \\
\hline & 4 & & & & & Brasov & 0 & 6876 & $45.6^{\circ} \mathrm{N}$ & $610 \mathrm{~m}$ \\
\hline & D3 & 10 & 10 & 60 & & Madrid & 106 & 2306 & $40.4^{\circ} \mathrm{N}$ & $667 \mathrm{~m}$ \\
\hline \multirow[t]{3}{*}{ Spain } & $\mathrm{C} 2$ & 10 & 10 & & $60 \%$ & Barcelona & 53 & 1597 & $41.3^{\circ} \mathrm{N}$ & $12 \mathrm{~m}$ \\
\hline & E1 & 5 & 15 & & & Burgos & 1 & 3407 & $42.2^{\circ} \mathrm{N}$ & $859 \mathrm{~m}$ \\
\hline & A4 & 15 & 5 & & & Huelva & 141 & 1205 & $37.15^{\circ} \mathrm{N}$ & $24 \mathrm{~m}$ \\
\hline
\end{tabular}

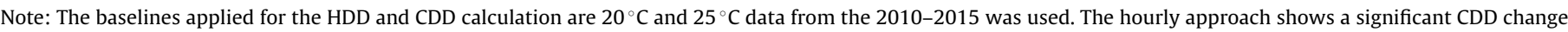
regarding day/night variation compared to the HDD.

a In France, $26^{\circ} \mathrm{C}$ is for air-conditioned buildings. For non-air-conditioned buildings, inner temperature should be lower than the reference indoor temperature (TIC REF) during 5 days. TIC REF is determined by standard computation and is depending of the climatic zone.

of an nZEB observatory for Southern Countries will help to create a database of monitored nZEB. EPCs and monitored data on real case studies needs to be collected, quantified and better shared. This can help in generating and consolidating regional knowledge and expertise taking stock from the Northern strongly influenced concept of nZEB, but enriching and adapting it to the variety of southern climates. Also, we should take into account European building related standards and norms, in order to address indoor environmental quality and the environmental impact assessment of materials. Private rating systems and standards, such as the $\mathrm{pH}$, LEED, DGNB and BREEAM or others, can also encourage the holistic design/build/operate approach through integrated project delivery processes, which is very important to foresee the future regulations related to well-being and environmental product declaration. We should consider the knowledge transfer between Southern MS as a good starting point to increase the knowledge uptake and accelerate the implementation of nZEB.

\subsubsection{Organizational - infrastructure}

On the organisation level, we recommend to take strong action for developing the needed human and industrial infrastructure for nZEB implementation. The empowerment of scientists, professionals, industrial stakeholders, policy makers and local authorities in Southern Europe makes them able to embrace the new transition. For example, we recommend empowering building researchers and allowing them to develop monitoring based concepts and definitions of nZEB and long term case study analysis and reasoning [58]. This includes the generation of new weather files (using recent hourly climate series and simulations of future climate with regional models [35]), climate comparisons, guidelines for passive cooling and efficient active cooling systems, grid interaction models and prepare for the following deep renovation challenge. This step involves creating an industrial strategy to empower the local industry to produce and supply buildings with ultra-efficient products and materials. We need new and different building design concepts that are geoclimatically developed respecting climate sensitivity and technological state of progress. Locally or regionally manufactured building components, products and materials should lead the market transformation.

\subsubsection{Legislation and enforcement}

Legislation should be based on an evidence-based policy strategy. Legislation must require permits and certification for renovation as well as new constructions which are capable to trace the renovation status, which is presently subject to extreme uncertainty, and building stock energy performance. This includes ensuring quality of construction works through quality checks, compliance procedures and proper commissioning. A project like QUALICHECK is a very good start to achieve the reliability of EPC declarations and the quality of the works [95]. The project ensures better enforcement and refurbishment in the frame of the revised EPBD, to create regulatory conditions to ensure better IEQ. This can also be achieved by ensuring regular inspections and continuous commissioning of passive systems and technical building systems of nZEB to maintain the envisaged IEQ parameters, EE, and RES production. This work should be tackled on a Pan-European level to unlock the relation between tenants and owners and support the acceleration of renovation rates. 


\subsubsection{Educational-awareness}

More attempts are needed to raise the awareness about energy neutral buildings and to discuss the strategic approach of SMEs to develop a suitable conceptual model for nZEB in Southern Europe. Professional education can bring advanced concepts and technologies to SMEs. We recommend better preparing the building professionals and providing vocational trainings while simplifying the design and construction process of nZEB. This includes educating professionals and one shop service providers and builders. Networking and awareness rising can bring various forms of strategic alliances, in addition, a strategic framework for improving nZEB quality and profitability for SMEs.

Regarding citizens, the rate and depth of renovation will increase when the added value (ecological and economical) will seem obvious to tenants and owners. In parallel, we suggest creating cooperatives with a focus on renovation service to members to provide strong direction towards deep renovation and to bring capital and investments for middle and large nZEB renovation projects. Evidence suggest that a part of the solution to speed up the uptake of nZEB and renovation process is to make energy neutrality of buildings desirable, and to use it as a self-esteem and social status perspective $[58,96]$.

\subsection{Study strengths, limitations and future research}

The methodology used in this paper was based on interviewing national experts from seven South European countries. We tried our best to find representative experts, however we focused mainly on researchers coming from national research institutions such as universities and research centres. In this case, the statistical representation cannot be claimed. The overview provided by experts is therefore prospective and our analysis and recommendations are experience based working hypothesis but need to be enriched and confirmed with further analysis. However, this study aims at covering a lack of cross comparison on the current trends and state of nZEB implementation in Southern Europe. This is very important because Southern Europe's buildings stock represent more than $33 \%$ of the European total residential building stock. Our identification of the main barriers of nZEB implementation and market uptake status identifies a common pattern in Southern Europe, which is in line with other studies including the ZEBRA2020 project [97]. We believe that we are in a transitional phase and facing new phenomena of building transformation and creation in Southern Europe. Therefore, we created an overview and adopted a critical approach to better understand nZEB and their implementation and more importantly, encourage the development and set up of local and climate adaptive models and concepts of nZEB. The strength of the study relies on its findings that reveal a misunderstanding of nZEB, regarding their energy and comfort performance in Southern Europe, and the lack of essential analysis of the nature of nZEB in Southern Europe. At the same time, the study suggests new recommendation and performance requirements that can help in supporting the decision making on a European and national level. Policy makers and funding agencies should respond accordingly and recognize that a full infrastructure needs to be deployed in Southern Europe, adequate to the urgency of the 2020 deadline. At present, nZEB in Southern Europe are to a certain extent more a research object than an actual implementation issue, which imposes new obligations on policy makers and funding agencies.

The next step for this research will be the cross comparison of representative low-tech and high tech nZEB case studies in Southern Europe. We aim also at including other countries in Southern Europe. We hope that the future work will start with the development of nZEB proofed concepts and definition to derive recommendations and strategies for the building industry in order to move to the large scale implementation and accelerate the market uptake of nZEB.

\section{References}

[1] European Commission, 2020 Climate \& Energy Package, European Commission, 2010 (Retrieved from) http://ec.europa.eu/clima/policies/ strategies/2020/index_en.htm.

[2] B. Atanasiu, T. Boermans, K.E. Thomsen, J. Rose, S. Aggerholm, A. Hermelink, M. Offermann, Principles for Nearly Zero Energy Buildings, 2011 (Retrieved from) http://www.forskningsdatabasen.dk/en/catalog/2186082897.

[3] M. Hamdy, K. Siren, S. Attia, Impact of financial assumptions on the cost optimality towards nearly zero energy buildings- a case study, Energy Build. (2017) (ISSN 0378-7788)

[4] S. Attia, Net Zero Energy Buildings (NZEB): Concepts, Frameworks and Roadmap for Project Analysis and Implementation, Elsevier, 2017 (ISBN: 978-0128124611)

[5] S. Pless, P. Torcellini, Getting to net zero, ASHRAE J. 51 (9) (2009) 18

[6] EPBD, Directive 2002/91/EG. Of the European Parliament and of the Council of 16 December 2002 on the energy performance of buildings, 2002 http:// europa.eu.int/comm/energy/demand/legislation/buildings_en.htm.

[7] EPBD recast, Directive 2010/31/EU of the European Parliament and of the Council of 19 May 2010 on the energy performance of buildings (recast), Off. J. Eur. Union (2010) (12/09/2016).

[8] H. Visscher, et al., The impact of energy performance regulations on systems of building control, RICS, COBRA Research Conference, University of Cape Town 10-11 (2009) 1356-1367.

[9] European Council for an Energy Efficient Economy (eceee), EPBD consultation, review, possible revision and nZEB: A methodological discussion and proposals by eceee, 2015 (Available from http://www.buildup.eu/en/node/ 49696, Accesses August 2017).

[10] E. Annunziata, M. Frey, F. Rizzi, Towards nearly zero-energy buildings: the state-of-art of national regulations in Europe, Energy (2013), http://dx.doi. org/10.1016/j. energy.2012.11.049.

[11] A. Hermelink, S. Schimschar, T. Boermans, L. Pagliano, P. Zangheri, R. Armani, K. Voss, E. Musall, Towards Nearly Zero-energy Buildings: Definition of Common Principles Under the EPBD Ecofys, University of Wuppertal, Politecnico di Milano -eERG., 2013.

[12] V. Badescu, N. Rotar, I. Udrea, Considerations concerning the feasibility of the German Passivhaus concept in southern Hemisphere, Energy Effic. 8 (5) (2015) 919-949.

[13] J. Schnieders, Passive Houses in South West Europe: a Quantitative Investigation of Some Passive and Active Space Conditioning Techniques for Highly Energy Efficient Dwellings in the South West European Region, Passivhaus Institut, 2009.

[14] J. Schnieders, W. Feist, L. Rongen, Passive Houses for different climate zones, Energy Build. 105 (2015) 71-87.

[15] EN 15251, Indoor environmental input parameters for design and assessment of energy performance of buildings addressing indoor air quality, thermal environment, lighting and acoustics, in: European Committee for Standardization, Brussels, Belgium, 2007.

[16] B. Givoni, Climate Considerations in Building and Urban Design, John Wiley \& Sons, 1998.

[17] L. Pagliano, S. Carlucci, T. Toppi, P. Zangheri, Passivhaus per il sud dell'Europa - Linee guida per la progettazione, Rockwool Italia, Milano, 2009.

[18] S. Carlucci, L. Pagliano, P. Zangheri, Optimization by discomfort minimization for designing a comfortable net zero energy building in the Mediterranean climate, 2013, http://dx.doi.org/10.4028/www.scientific.net/AMR.689.44.

[19] S. Attia, S. Carlucci, Impact of different thermal comfort models on zero energy residential buildings in hot climate, Energy Build. 102 (2015) 117-128.

[20] L. Pagliano, P. Zangheri, Comfort models and cooling of buildings in the Mediterranean zone, Adv. Build. Energy Res. 4 (1) (2010) 167-200.

[21] L. Pagliano, P. Zangheri, A. Pindar, J. Schnieders, The passivhaus standard in southern europe, in: Paper Presented at the 2nd PALENC Conference and 28th AIVC Conference in the 21st Century, Crete Island, Greece, 2007

[22] M. Pietrobon, L. Pagliano, Mediterranean passive house solutions towards nearly zero energy buildings in Italian regions, in: Paper Presented at the 18th Passivhaus Conference, Aachen, 2014.

[23] F. Causone, S. Carlucci, L. Pagliano, M. Pietrobon, A zero energy concept building for the mediterranean climate, Energy Procedia 62 (2014) 280-288, http://dx.doi.org/10.1016/j.egypro.2014.12.389.

[24] R. Barbosa, M. Barták, J.L. Hensen, M.G. Loomans, Ventilative cooling control strategies applied to passive house in order to avoid indoor overheating, 2015

[25] I. Ridley, A. Clarke, J. Bere, H. Altamirano, S. Lewis, M. Durdev, A. Farr, The monitored performance of the first new London dwelling certified to the Passive House standard, Energy Build. 63 (2013) 67-78.

[26] E. Mlecnik, H. Visscher, A. Van Hal, Barriers and opportunities for labels for highly energy-efficient houses, Energy Policy 38 (8) (2010) 4592-4603.

[27] A.D. Peacock, D.P. Jenkins, D. Kane, Investigating the potential of overheating in UK dwellings as a consequence of extant climate change, Energy Policy 38 (7) (2010) 3277-3288.

[28] E.E.I. Unit, Investing in Energy Efficiency in Europe's Buildings: a View from Construction and Real Estate Sectors, Committed by GPBN, WBCSD, BPIE, 2013. 
[29] A. Figueiredo, J. Kämpf, R. Vicente, Passive house optimization for Portugal: overheating evaluation and energy performance, Energy Build. 118 (2016) 181-196.

[30] S. Carlucci, L. Pagliano, A. Sangalli, Statistical analysis of the ranking capability of long-term thermal discomfort indices and their adoption in optimization processes to support building design, Build. Environ. 75 (2014) $114-131$.

[31] L. Pagliano, P. Zangheri, Comfort models and cooling of buildings in the Mediterranean zone, Adv. Build. Energy Res. 4 (1) (2010) 167-200.

[32] S. Carlucci, L. Pagliano, W. O’Brien, K. Kapsis, Comfort considerations in Net ZEBs: theory and design, in: A. Athienitis, W. O'Brien (Eds.), Model. Des. Optim. Net-Zero Energy Build., Wilhelm Ernst \& Sohn, Berlin, Germany, 2015, pp. 75-106, http://dx.doi.org/10.1002/9783433604625.ch03.

[33] S. Carlucci, L. Pagliano, P. Zangheri, Optimization by discomfort minimization for designing a comfortable net zero energy building in the Mediterranean climate, Adv. Mater. Res. 689 (2013) 44-48 (Trans Tech Publications).

[34] Pagliano Carlucci, et al., Zero energy living lab, book chapter, in: J. Littlewood (Ed.), Smart Energy Control Systems for Sustainable Buildings, Smart Innovation, Systems and Technologies, 2016, p. 67, http://dx.doi.org/10.1007/ 978-3-319-52076-6_1.

[35] L. Pagliano, S. Carlucci, F. Causone, A. Moazami, A. Cattarin, Energy retrofit for a climate resilient child care centre, Energy Build. 127 (2016) 1117-1132, http://dx.doi.org/10.1016/j.enbuild.2016.05.092.

[36] EnOB, Monitor Database for Monitoring Data for Innovative Operating Strategies of Buildings, German Federal Ministry of Economic Affairs and Energy (BMWi), 2015 (Available from: enob.ise.fraunhofer.de Accessed June 2017).

[37] H. Bruyninckx, Belgian Air Quality One of the Worst in Europe, The Brussels Times, 2016 (1 May 2017)

[38] S.M. Da Silva, M.G. Almeida, L. Bragança, M. Carvalho, nZEB Training Needs in the Southern EU Countries - SouthZEB project, Latin-American and European Encounter on Sustainable Building and Communities - Connecting People and Ideas, vol. 3, 2015, pp. 2469-2478 (978-989-96543-8-9).

[39] B. Ford, R. SchianoPhan, D. Zhong, The Passivhaus Standard in European warm climates: design guidelines for comfortable low energy homes, in: School of the Built Environment, University of Nottingham, 2007.

[40] EERG, The Passive-On Project, Passive Houses amd the Passivhaus Standard in warm climates, 2007 (Availbelf from: http://www.eerg.it/passive-on.org/en/. Accessed 2 June 2017).

[41] H. Erhorn, H. Erhorn-Kluttig, S. Doster, Towards improved quality of the works -Documented examples of existing situations regarding quality of works, Brussels (2015).

[42] S. Attia, P. Eleftheriou, F. Xeni, R. Morlot, C. Ménézo, V. Kostopoulos, M. Betsi, I. Kalaitzoglou, M. Almeida, M. Ferreirag, T. Baracuh, V. Badescuh, R. Crutescui, J.M. Hidalgo-Betanzos, L. Pagliano, (2016) Overview of challenges of residential nearly Zero Energy Buildings (nZEB) in Southern Europe, Sustainable Buildings Design Lab, Technical Report, Liege, Belgium, 9782930909059.

[43] Cyprus Energy Service, Thermal Insulation Guide, 2nd edition, Ministry of Energy Commerce Industry and Tourism, Nicosia, NIC, 2009.

[44] CyStat, Final Energy Consumption in Households, Ministry of Interior, Cyprus, Nicosia, NIC, 2009

[45] Cyprus Energy Service, National Methodology for Assessing the Energy Performance of Buildings, Ministry of Energy Commerce Industry and Tourism, Nicosia, NIC, 2009.

[46] F. Xeni, P. Eleftheriou, N. Paraskeva, Retrofitting Towards nZEB -a Cyprus Case Study for Residential Buildings, Splitech, 2016, P2-69793-1307.

[47] FR, Arrêté du 26 octobre 2010 relatif aux caractéristiques thermiques et aux exigences de performance énergétique des bâtiments nouveaux et des parties nouvelles de bâtiments, Journal Officiel de la République Française (2010), n 0250 du 27 octobre 2010 page 19260 (see https://www.legifrance.gouv.fr/ eli/arrete/2010/10/26/DEVU1026270A/jo/texte).

[48] FR, Règles techniques applicables aux bâtiments faisant l'objet d'une demande de Label BEPOS-effinergie 2013, 2015 (Version 3, 6 pages. 8 Septembre 2015).

[49] n.d., 2016. Climate zones of Greece. Retrieved from http://microboiler.eu/wpcontent/uploads/2013/06/.

[50] K.T. Papakostas, P. Zagana-Papavasileiou, T. Mavromatis, Analysis of 3 decades temperature data for Athens and Thessaloniki, Greece-impact of temperature changes on energy consumption for heating and cooling of buildings, 2016 (Retrieved from) http://uest.ntua.gr/adapttoclimate/proceedings/full_paper/ PAPAKOSTAS-ZAGANA-MAVROMATIS.pdf.

[51] Italian Climate Zones, (1993) Presidential Decree n. 412 of 26 August 1993 Annex A.

[52] Jean-Marie Robine, Siu Lan Cheung, Sophie Le Roy, Herman Van Oyen, Clare Griffiths, Jean-Pierre Michel, François Richard Herrmann, Death toll exceeded 70,000 in Europe during the summer of 2003, C. R. Biol. 331 (2) (2008) 171-178, http://dx.doi.org/10.1016/j.crvi.2007.12.001 (ISSN 1631-0691.PMID 18241810)

[53] M. Santamouris, D. Kolokotsa, On the impact of urban overheating and extreme climatic conditions on housing, energy, comfort and environmental quality of vulnerable population in Europe, Energy Build. 98 (2015) 125-133, http://dx.doi.org/10.1016/j.enbuild.2014.08.050.

[54] A. Sakka, M. Santamouris, I. Livada, F. Nicol, M. Wilson, On the thermal performance of low income housing during heat waves, Energy Build. 49 (2012) 69-77, http://dx.doi.org/10.1016/j.enbuild.2012.01.023.
[55] F. Ascione, R.F. De Masi, F. de Rossi, S. Ruggiero, G.P. Vanoli, Optimization of building envelope design for nZEB in Mediterranean climate: performance analysis of residential case study, Appl. Energy 183 (2016) 938-957.

[56] F. Guarino, S. Longo, G. Tumminia, M. Cellura, M. Ferraro, Ventilative cooling application in Mediterranean buildings: impacts on grid interaction and load match, Int. J. Vent. (2016) 1-13.

[57] M. Santamouris, Cooling the buildings - past, present and future, Energy Build. 128 (2016) 617-638, http://dx.doi.org/10.1016/j.enbuild.2016.07.034

[58] M. Garthley, F. Mischler, F. Geyer, J. Nejc, M. Vlainić, C. Csaczar, K. Simeonov, D. Tzanev, EmBuild - Empower public authorities to establish a long-term strategy for mobilizing investment in the energy efficient renovation of the building stock, European Union Research and Innovation Programme Under Grant Agreement No 695169 (2017).

[59] Portugal, Regulamento de Desempenho Energético dos Edifícios de Habitação (REH) - Requisitos de conceção para edifícios novos e intervenções, 2015 (Portaria no 379-A/2015 de 22 de outubro).

[60] J. Fernandes, C. Pimenta, R. Mateus, S. Silva, L. Bragança, Contribution of portuguese vernacular building strategies to indoor thermal comfort and occupants' perception, Buildings 5 (2015) 1242-1264, http://dx.doi.org/10. 3390/buildings5041242.

[61] A. Cortez, Estratégias construtivas passivas para a conceção de edifícios residenciais não dependentes de sistemas ativos de arrefecimento, in: Tese-Mestrado Integrado Em Engenharia Civil, University of Minho, Guimarães, 2016

[62] P.M.A. Miranda, F.E.S. Coelho, A.R. Tomé, M.A. Valente, A. Carvalho, C. Pires, H.O. Pires, V.C. Pires, C. Ramalho, 20th century portuguese climate and climate scenarios, in: F.D. Santos, K. Forbes, R. Moita (Eds.), 2002, Climate Change in Portugal: Scenarios, Impacts and Adaptation Measures (SIAM Project), Gradiva, 2002, pp. 23-83 (454 pp).

[63] L. Matias, TPI65 - Desenvolvimento de um Modelo Adaptativo Para Definição das Condições de Conforto Térmico em Portugal, Laboratório Nacional de Engenharia Civil/National Laboratory of Civil Engineering, Lisboa, Portugal, 2010.

[64] ANSI/ASHRAE Standard 55, Thermal Environmental Conditions for Human Occupancy, American Society of Heating, Refrigerating, and Air-Conditioning Engineers (ASHRAE), Atlanta, GA, USA, 2010.

[65] L. Matias, S. Almeida, C. Pina Santos, M. Rebelo, M. Correia Guedes, Adaptive thermal comfort for buildings in Portugal based on occupants' thermal perception, in: Proceedings of the PLEA2009Les Presses De l'Université Laval, Quebec City, Canada, 2009, pp. 22-24.

[66] J. Healy, Excess winter mortality in Europe: a cross country analysis identifying key risk factors, J. Epidemiol. Community Health 2003 (57) (2003) 784-789, http://dx.doi.org/10.1136/jech.57.10.784.

[67] L. Desvallees, (2016), Mais il ne fait pas froid au Portugal! Comment une forme de pauvreté politiquement invisible affecte les ménages de Porto, Instituto de Sociologia IS Working Paper, 3 - - Série, $\mathrm{N}^{\circ} 10$

[68] S.M. Silva, M.G. Almeida, L. Bragança, M. Carvalho, nZEB Training Needs in the Southern EU Countries - SouthZEB project, Latin-American and European Encounter on Sustainable Building and Communities - Connecting People and Ideas, 2015, pp. 2469-2478 (978-989-96543-8-9).

[69] Ordinul nr. 386, pentru modificarea şi completarea Reglementării tehnice Normativ privind calculul termotehnic al elementelor de construcție ale clădirilor, Ministerul Dezvoltării Regionale și Administrației Publice, Bucuresti, 2016.

[70] N. Ionac, M. Matei, The influence of european climate variability mechanism on air temperatures in Romania, PESD 8 (1) (2014) 5-16.

[71] A. Manea, M.-V. Birsan, G. Tudorache, F. Carbunaru, Changes in the type of precipitation and associated cloud types in Eastern Romania (1961-2008) Atmos. Res. 169 (2016) 357-365

[72] A.A. Muresan, S. Attia, Energy efficiency in the Romanian residential building stock, Renew. Sustain. Energy Rev. 74 (2017) 349-363, http://dx.doi.org/10. 1016/j.rser.2017.02.022 (ISSN: 1364-0321).

[73] Asociatia Romana de Standardizare (ASRO) (2006), SR EN ISO 7730:2006 Ambiante termice moderate. Determinarea analitica si interpretarea confortului termic prin calculul indicilor PMV si PPD si specificarea criteriilor de confort termic local, Bucuresti, Romania.

[74] I. Udrea, C. Croitoru, I. Nastase, R. Crutescu, V. Badescu, An adaptive thermal comfort model for the romanian climate, in: A. Sayigh (Ed.), Mediterranean Green Buildings \& Renewable Energy, Springer International Publishing, Switzerland, 2016 (ch. 73)

[75] Spain, (2017) Real Decreto 564/2017, de 2 de junio, por el que se modifica el Real Decreto 235/2013, de 5 de abril, por el que se aprueba el procedimiento básico para la certificación de la eficiencia energética de los edificios. Boletín Oficial del Estado de 6 de junio de 2017, pp 45925-45937.

[76] Ministry of Development, Spain, Spain, Documento de bases para la actualización del Documento Básico DB-HE, 2013

[77] Ministry of Industry, Energy and Tourism, Spain, Reglamento de Instalaciones Térmicas en los Edificios, versión consolidada, 2013; I. Rodriguez-Vidal, (2015) Evaluación del estándar de construcción Passivhaus y su aplicación en el ámbito climático de la Comunidad Autónoma, PhD Thesis, Biscay, Spain.

[78] C. Torre Minguela, I. De González Pérez, A. Gordaliza Pastor, M. García-Fuentes Á, D. Romera Pascual, Rehabilitación energética del barrio residencial Fasa-Renault con criterios de distrito de Energía Casi Nula dentro del marco del Proyecto Faro Remourban, in: Proceedings III Congreso edificios energía casi nula, Madrid, 2016, pp. 390-395 (ISBN 978-84-608-8686-0). 
[79] L. Aelenei, H. Petran, J. Tarrés, G. Riva, A. Ferreira, S. Camelo, V. Corrado, M. Šijanec-Zavrl, G. Stegnar, H. Gonçalves, Z. Magyar, J. Salom, E. Polychroni, K. Sfakianaki, New challenge of the public buildings: nZEB findings from IEE RePublic_ZEB project, Energy Procedia 78 (2015) (2016) 2016-2021, http://dx. doi.org/10.1016/j.egypro.2015.11.195 (ISSN 1876-6102).

[80] R. Ruíz-Cuevas, S. Pascual Solá, I. Agudiez Andrés, Sí es posible la ventilación con recuperación de calor en rehabilitación -rehabilitación energética de bloque de viviendas en Zaramaga, in: Proceedings III Congreso edificios energía casi nula, Madrid, 2016, pp. 402-407 (ISBN 978-84-608-8686-0).

[81] D. Azofra, J.C. Saenz-Díez, E. Martínez, E. Jiménez, J. Blanco, Ex-post economic analysis of photovoltaic power in the Spanish grid: alternative scenarios, Renew. Energy 95 (2016) 98-108.

[82] B. Boardman, Fixing Fuel Poverty: Challenges and Solutions, Routledge, 2013.

[83] E. Kontonasiou, B. Atanasiu, F. Mariottini, Fuel poverty mitigation through energy efficiency in buildings, 2015 (Retrieved from http://bpie.eu/wpcontent/uploads/2015/10/BPIEposter-Fuel-Poverty20151.pdf, Accessed 10 October 2016)

[84] M. Santamouris, Innovating to zero the building sector in Europe: minimising the energy consumption: eradication of the energy poverty and mitigating the local climate change, Sol. Energy 128 (2016) 61-94.

[85] S. Attia, Hamdy, et al., Computational optimisation for zero energy buildings design interviews results with twenty eight international expert, in: International Building Performance Simulation Association, August, Chambery France, 2013.

[86] S. Attia, A. De Herde, Early design simulation tools for net zero energy buildings: a comparison of ten tools, in: International Building Performance Simulation Association, November 2011, Sydney, Australia, 2011.

[87] P. Ciais, M. Reichstein, N. Viovy, A. Granier, J. Ogée, V. Allard, F. Chevallier, Europe-wide reduction in primary productivity caused by the heat and drought in 2003, Nature 437 (7058) (2005) 529-533.
[88] M. Baccini, A. Biggeri, G. Accetta, T. Kosatsky, K. Katsouyanni, A. Analitis, B. Forsberg, Heat effects on mortality in 15 European cities, Epidemiology 19 (5) (2008) 711-719.

[89] R. Mcleod, C. Hopfe, A. Kwan, An investigation into future performance and overheating risks in Passivhaus dwellings, Build. Environ. 70 (2013) 189-209.

[90] J. Mlakar, J. Štrancar, Overheating in residential passive house: solution strategies revealed and confirmed through data analysis and simulations, Energy Build. 43 (6) (2011) 1443-1451.

[91] R.S. McLeod, C.J. Hopfe, A. Kwan, An investigation into future performance and overheating risks in Passivhaus dwellings, Build. Environ. 70 (2013) 189-209.

[92] S.M.T. Sameni, M. Gaterell, A. Montazami, A. Ahmed, Overheating investigation in UK social housing flats built to the Passivhaus standard, Build. Environ. 92 (2015) 222-235.

[93] J. Schnieders, Passive Houses in South West Europe: a quantitative investigation of some passive and active space conditioning techniques for highly energy efficient dwellings in the South West European region, 2nd corrected ed., 2009 (Available at: www.passiv.de).

[94] BPIE, (2017). Breakdown of the building stock by building type in EU. In: The BPIE Data Hub for the Energy Performance of Buildings. Brussels. Retrieved from: http://www.buildingsdata.eu/.

[95] QUALICHeCK, Overview of existing surveys on energy performance related quality and compliance, 2015, http://qualicheck-platform.eu/2015/06/reportstatus-on-the-ground/ (Accessed June 2017).

[96] ZEBRA 2020 Data Tool, Energy efficiency trends in buildings, 2016 (Available from: http://www.zebra-monitoring.enerdata.eu/overall-building-activities/ nzeb-definitions-by-country.html, Accessed August 2017).

[97] Å.L. Hauge, J. Thomsen, E. Löfström, How to get residents/owners in housing cooperatives to agree on sustainable renovation, Energy Effic. 6 (2) (2013) 315-328. 